\title{
The Cycles of Statutory Interpretation
}

\author{
Adrian Vermeule $\dagger$
}

This Article advances an explanation of interpretive change-the fact that the Supreme Court frequently changes the nominal formulation of its rules for statutory interpretation, and to some degree changes its actual interpretive practice as well. The prevailing styles of explanation attribute interpretive change to exogenous shocks such as a change in the party composition of the legislature or a string of judicial appointments. The Article criticizes the exogenous explanatory style on methodological grounds, and advances an alternative model that attributes interpretive change to endogenous shifts in the expectations of actors in the interpretive system. In particular, the Article develops a positive cycling model in which legislators and judges develop self-defeating expectations about the behavior of other actors in the lawmaking system, thereby causing a cyclical pattern of continuous mutual adjustment that never reaches a stable equilibrium. The Article concludes with some casual empiricism that is consistent with the cycling model but problematic for the exogenous explanations.

How stable is interpretive doctrine - the set of canons, principles, and rules that American courts use in statutory interpretation? At a high level of abstraction, the answer is "very stable." Since the decline of the "equity of the statute" idea in the mid-nineteenth century," American courts have conceived statutory interpretation as an exercise in implementing legislative instructions and have used a familiar list of sources and techniques to ascertain those instructions.

But that level of abstraction is too airy to be interesting. Add some detail and the picture changes sharply; interpretive doctrine appears markedly unstable, fluctuating rather dramatically over short periods. Considering only the output of the United States Supreme Court on subjects such as the role of purposive considerations in interpretation, the use of extrinsic (or nontextual) sources, and the role of particular canons of construction, the Court has changed its practice, and sometimes the formally stated rules, with remarkable frequency. ${ }^{2}$ Realists may believe that such doctrines have no causal influence on judges' decisionmaking, but if that is true-especially if that is true-it is a puzzle for the realist why the Court bothers to change its verbal formulations at all.

$\dagger$ Professor of Law, The University of Chicago. Thanks to Douglas Baird, Elizabeth Garrett, Jack Goldsmith, Daryl Levinson, Saul Levmore, John Manning, Eric Posner, Cass Sunstein, and David Weisbach for helpful comments and to participants at workshops at the University of Virginia Law School and the University of Texas Law School. Stephanie Morris provided excellent research assistance. Special thanks to Yun Soo Vermeule. I am grateful for the support of the Russell J. Parsons Research Fund.

1 See John F. Manning, Textualism and the Equity of the Statute, 101 Colum L Rev 1 (forthcoming 2001) (examining the history of "equitable" considerations in English and American statutory interpretation).

2 For examples of such instability, see Part II.B. 
Why does interpretive doctrine display this degree of instability? The literature shows little or no interest in the question, partly because the literature is largely uninterested in positive questions of any sort (with honorable exceptions), and partly because of a pervasive assumption that changes in interpretive doctrine are the products of changes in variables exogenous to the interpretive system. Interpretive change, when it is discussed at all, is approached through two major styles of explanation, both of which share the exogeneity assumption. The older style of explanation treats the history of statutory interpretation as a subfield of the intellectual history of the law or even of intellectual history generally. On this view, changes in interpretive doctrine are caused by conceptual or ideological change in the wider society-by the spirit of the age. A newer style of explanation depicts interpretive doctrine as an equilibrium reached in a sequential game among lawmaking institutions. On this view, changes in the institutional equilibrium result from exogenous disturbances, such as a string of judicial appointments or an election that changes the composition of the legislature. Together, the intellectual-history approach and the political-equilibrium approach suggest that changes in interpretive doctrine are the product of exogenous causes, so nothing interestingly general can be said about the pattern of change, absent some largescale account of political or social change itself.

In this Article, a positive rather than normative effort, I shall suggest a very different sort of explanation for the instability of interpretive doctrine. Rather than treating interpretive change as the product of exogenous causes, I shall explore a variety of wholly endogenous mechanisms, internal to the institutional system of statutory enactment and interpretation, that might cause the instability of interpretive doctrine. My basic strategy is to explore the possibility that interpretive doctrine displays a regular tendency to oscillate, or cycle, over a defined range of positions on major doctrinal questions. On this view, the cycling of interpretive theory is the product of self-defeating expectations $^{3}$ held by legislators, litigants, and judges. The cycling mechanisms I shall discuss have the following features in common: one actor in the interpretive system, $A$, forms expectations that cause $A$ to engage in behavior that causes another actor, $B$, to form expectations that cause $B$ to engage in behavior that contradicts $A$ 's initial expectations; which in turn causes $A$ to engage in behavior that contradicts $B$ 's initial expectations, with a resulting reversal in $B$ 's behav-

3 For an introduction to self-fulfilling and self-defeating expectations, see Andre Kukla, The Structure of Self-fulfilling and Self-negating Prophecies, 4 Theory \& Psych 5-33 (1994); Thomas C. Schelling, Micromotives and Macrobehavior 115-19 (W.W. Norton 1978). 
ior; that reversal revives $A$ 's initial expectations, which causes behavior that revives $B$ 's initial expectations; and so on."

I shall explore two principal classes of cycling mechanisms relevant to interpretive change: litigation mechanisms and legislativeprocess mechanisms. Litigation mechanisms posit that the behavior of litigants and judges in statutory cases will cause judge-made interpretive doctrine to oscillate between literalist and purposivist readings of general statutory texts, or between competing interpretive sources such as text and legislative history. The critical feature of these mechanisms is that the judges' choice of doctrine affects the pool of cases that are litigated or settled and, consequently, the pool of cases that later judges observe. That pool of cases will expose the defects of the current approach, causing judges to switch to an alternate rulewhereupon the same process occurs again, causing the reinstatement of the rule previously chosen, and a cyclical pattern arises. Although the few previous applications of cycling models to law ${ }^{5}$ have focused upon litigation mechanisms, the idea lacks true explanatory power because it is too general. Litigation mechanisms can explain cycling in any field of common law or legal interpretation in which judges adjudicate cases, which is to say most fields. But clearly cycling does not always occur, and some areas of legal doctrine are quite stable. Litiga-

4 Cycling mechanisms of this sort are well known in economics, history, and the social sciences. Many of these models assume some form of limited rationality on the part of social actors (as do I). See Part I.D. In macroeconomics and public choice, the "political business cycle" literature supposes that governments attempt to adjust unemployment and inflation so as to ensure re-election; these models assume that voters are myopic. See Dennis C. Mueller, Public Choice II 277-86 (Cambridge 1989). In microeconomics, cycles of oversupply and undersupply in certain industries have been explained both by rational expectations models, see, for example, Sherwin Rosen, Kevin M. Murphy, and Jose A. Scheinkman, Cattle Cycles, 102 J Pol Econ 468 (1994), and by models (such as the "cobweb cycle") that assume bounded rationality on the part of producers, see Jon Elster, Logic and Society: Contradictions and Possible Worlds 111-13 (Wiley 1978). In politics, Arthur Schlesinger advances a cyclical model of American political history, see Arthur Schlesinger, Jr., The Cycles of American History (Houghton Mifflin 1986), while Albert O. Hirschman uses a cycling model to explain the periodic turn toward public affairs, followed by a turn to private life, that characterizes recent American history, see Albert O. Hirschman, Shifting Involvements: Private Interest and Public Action 3-8 (Princeton 1982).

5 Legal applications of cycling models have to date appeared only infrequently, and only in the common law subjects. Leading examples are Jason Scott Johnston, Uncertainty, Chaos, and the Torts Process: An Economic Analysis of Legal Form, 76 Cornell L Rev 341, 356-62 (1991) (discussing cycling between rules and standards in judge-made tort doctrine); Carol M. Rose, Crystals and Mud in Property Law, 40 Stan L Rev 577 (1988) (discussing cycling between crystalline legislative rules and muddy judicial standards in property law); P.S. Atiyah, The Rise and Fall of Freedom of Contract (Clarendon 1979) (discussing historical cycling between rules and standards in British contract law). There are also some very abstract economic models of oscillation in the development of common law doctrine. See, for example, Douglas Glen Whitman, Evolution of the Common Law and the Emergence of Compromise, 29 J Legal Stud 753 (2000); Robert Cooter and Lewis Kornhauser, Can Litigation Improve the Law without the Help of Judges?, $9 \mathrm{~J}$ Legal Stud 139 (1980). 
tion mechanisms are hard pressed to explain when cycling will occur and when it will not.

Legislative-process mechanisms provide a more nuanced and more promising account of interpretive change by incorporating an account of legislative behavior. Positive analyses of interpretive theory have previously assumed that approaches such as textualism and intentionalism create self-fulfilling equilibria, in which judges' choice of interpretive doctrines causes legislators, within limits, to behave in accordance with the judges' expectations. By contrast, I shall explore the conditions under which the expectations that legislators and judges develop about the behavior of other actors in the lawmaking system prove self-defeating rather than self-fulfilling, causing a cyclical pattern of continuous mutual adjustment that never reaches a stable equilibrium. For example, judicial recourse to legislative history might cause legislators to manipulate the history in order to influence judges, in turn causing judges to eschew the history in the belief that it is corrupt, in turn causing legislators to cease their efforts to corrupt it, in turn causing judges to resume its use, and so forth. The particular example is contestable and receives more detailed scrutiny below, but describing the mechanism of mutually self-defeating expectations clarifies the conditions under which textualist, intentionalist, and other approaches to statutory interpretation prove stable or unstable.

There are two general qualifications to my project that should be emphasized at the outset. The first is that these cycling mechanisms, like most causal mechanisms, support explanations but rarely provide detailed, falsifiable predictions. ${ }^{6}$ Cycling mechanisms put some theoretical backbone in the casual impression, widespread among students of interpretation, that there is a discernible ebb and flow to interpretive doctrine. But these mechanisms can be specified in sufficiently many ways - in particular the period of the cycle can be stretched or contracted - that a decisive test of a cycling hypothesis is unlikely. The second, related qualification is that the impetus to explore cycling mechanisms is methodological, not substantive. Cycling mechanisms are a neglected type of endogenous explanation for legal change, and I shall argue that we should subscribe to a weak methodological preference for endogenous over exogenous explanations. The interpretive system, however, is surely susceptible to influence from external political, social, and intellectual change, so endogenous explanations in the end can only supplement, rather than replace, the standard approaches.

6 See Jon Elster, A Plea for Mechanisms, in Peter Hedstrom and Richard Swedberg, eds, Social Mechanisms: An Analytical Approach to Social Theory 45, 45-73 (Cambridge 1998).

7 See text accompanying notes 71-72. 
The discussion is organized as follows. Part I explains the litigation mechanisms and legislative-process mechanisms, and examines the assumptions on which they rest. Most importantly, the cycling mechanisms discussed here all assume a restricted form of adaptive learning on the part of legislators, judges, litigants, and other actors in the interpretive system. That assumption is inconsistent with strong versions of rational expectations theory. But I shall suggest that there is no particular reason to find the strong rational expectations hypothesis plausible in this setting. Interpretive actors work in a nonmarket institution that lacks the disciplining forces needed to sustain the rational expectations thesis.

Part II illustrates the strengths and weaknesses of the cycling mechanisms by reference to selected problems of interpretive doctrine, comparing the endogenous explanations for interpretive change to the prevailing styles of explanation, which ascribe interpretive change to exogenous intellectual or political change. I critique the methodological utility of exogenous explanations, while showing that endogenous cycling mechanisms provide a better account for the history of some interpretive doctrines and a plausible account for others (although the limitations of the evidence hamper the assessment). The upshot is that the cycling mechanisms rest upon strong assumptions, are of limited methodological utility, and provide a contestable explanation of the evidence. On all three dimensions, however, they show at least as much promise as the prevailing exogenous styles of explanation.

\section{CYCLING MECHANISMS}

This Part sketches two classes of endogenous mechanisms that might cause cyclical change in interpretive doctrine. Part I.A examines litigation mechanisms. Jason Johnston's important model of rulesstandards cycling in tort law is relevant here, and I adapt it to explain judicial oscillation between rigid and flexible readings of general textual mandates. Yet the rules-standards cycle is not the only relevant cycling mechanism that the litigation process might generate. A separate possibility is that the litigation process can generate judicial oscillation between different interpretive sources, such as text and legislative history, even if the competing sources are all read to embody either rules or standards. Litigation mechanisms, however, are insufficiently nuanced; they explain observed cycling in any domain of adjudication-statutory, constitutional, or common law-but provide no account of why cyclical alternation between legal rules occurs in some areas but not in others.

Part I.B examines a set of narrower legislative-process mechanisms. The various camps of statutory interpretation theorists assume 
that their preferred approaches will generate self-fulfilling expectations, with a resulting stable equilibrium. Sophisticated intentionalists, drawing upon positive political theory, argue that if courts consult legislative history to ascertain legislative "intent," then legislators who anticipate judicial behavior will engage in monitoring to ensure that legislative history accurately reflects the consensus of the enacting coalition. Sophisticated textualists, by contrast, argue that judicial emphasis on text will induce legislators to encode their deals in text, with beneficial consequences. The disagreement is about which stable equilibrium to choose, as between two alternatives that might arise through self-fulfilling judicial expectations. But there is a third possibility: the initial judicial choice of an interpretive approach might, given certain conditions, generate a cycle of self-defeating expectations that will cause legislators to take actions that cause judges to oscillate between textualism and intentionalism.

Part I.C relaxes these mechanisms' general assumption that the relevant court is staffed by a single judge. Introducing multi-judge courts requires consideration of the interactions between doctrinal cycles and a different form of "cycling": voting cycles that may arise (or be suppressed only by structure-induced equilibrium) on a multijudge panel. ${ }^{8}$ Finally, Part I.D explains and defends the assumptions about judicial information and learning that underpin the cycling mechanisms.

\section{A. Litigation Mechanisms}

Here I shall discuss two litigation-process mechanisms that might cause doctrinal cycling. The first is adapted from Jason Johnston's model of rules-standards cycling in tort law; it explains how judges might cycle between rule-like and standard-like interpretation of general statutory commands. The second explains how judges might display cyclical preferences for certain interpretive sources over other sources, regardless of whether the sources embody rules or standards.

\section{Rules-standards cycling.}

A recurring problem in statutory interpretation arises when a litigant claims that a facially unqualified statutory rule should be read in a flexible, standard-like fashion, with the content of the standard generated by some conception of legislative purpose. "No vehicles in the park" might or might not prohibit bicycles; a prohibition on contracting for immigrants to perform "labor or service of any kind"

8 I explain the term "voting cycles" and the difference between voting cycles and doctrinal cycles in Part I.C.2. 
might or might not apply to an immigrant minister of the gospel.' Many of the most dramatic and frequently discussed cases in American interpretive history are of this sort, and much of interpretive theory is devoted to competing arguments for and against formalist (rulelike) or antiformalist (standard-like) treatment of such cases. ${ }^{10}$

On certain assumptions about judicial behavior and litigants' responses to that behavior, judges will oscillate between rule-like and standard-like treatment of general statutory commands. Jason Johnston has proposed an analogous model in tort law. Suppose that courts developing tort doctrine initially choose a rule-say, that drivers at train crossings must stop, get out of the car, and check the track in both directions. ${ }^{11}$ But litigants, knowing of the rule, will tend to pursue precisely those cases in which the rule fits exceptionally poorly with its underlying justifications, ${ }^{12}$ and thus displays even more than the usual over- and underinclusiveness of rules (perhaps a case in which leaving the car would increase the danger to the driver). If judges evaluate the utility of the rule by reference to the sample of litigated cases brought before them, they will eventually come to consider the rule remarkably mistailored, and the temptation to substitute an equivalent standard will be great."

Litigants' responses to the new standard, however, will eventually cause an equal and opposite reaction. Under a standard or a balancing test, extreme cases will go unlitigated or will quickly be selected out of the litigation system through settlement. If the standard instructs drivers to "behave carefully at train crossings," the estate of the driver who crossed the tracks at breakneck speed will not contest a suit based on the resulting death, while the driver who engages in extensive precautions at crossings will not suffer an injury in the first place. Rather, under a standard, the most frequently litigated cases are the

9 See Church of the Holy Trinity $v$ United States, 143 US 457 (1892) (interpreting the provision not to cover a minister).

10 Consider Symposium: Formalism Revisited, Formalism and Statutory Interpretation, $66 \mathrm{U}$ Chi L Rev 635-708 (1999) (principal paper by Cass R. Sunstein, with comments by William N. Eskridge Jr., John F. Manning, and Adrian Vermeule).

11 See Baltimore \& Ohio Railroad Co v Goodman, 275 US 66, 70 (1927) (Holmes) (suggesting such a rule). The example is adapted from Johnston, 76 Cornell $L$ Rev at 350-62 (cited in note 5).

12 There is an assumption here that the clarity of the rule, where clarity is partly a function of the fit between the rule's terms and its underlying purposes, is a principal determinant of settlement. For a defense of this assumption by reference to the standard law and economics account of settlement, in which parties are less likely to settle cases in which the outcome is unclear or uncertain, see Johnston, 76 Cornell L Rev at $356 \mathrm{n} 35$ (cited in note 5). For a recent more detailed examination of the determinants of settlement, including cognitive biases as well as expected utility, see Chris Guthrie, Framing Frivolous Litigation: A Psychological Theory, $67 \mathrm{U}$ Chi L Rev 163 (2000).

13 See Pokora v Wabash Railway Co, 292 US 98, 104-06 (1934) (Cardozo) (criticizing the Goodman test as insufficiently sensitive to circumstances). 
intermediate cases, those in which the defendant drove with some care and yet happened to be killed or injured. Observing a stream of rather similar, intermediate cases, judges will be tempted to generalize a rule, such as the stop-and-check rule. After all, the similarity of the litigated cases ensures that the rule will not prove terribly over- or underinclusive, so that the usual benefits of rules - their relative certainty and adjudicative efficiency - can be obtained at a reasonable price. The cycle begins again when litigants probe the new rule by bringing to court not the typical cases from which the rule was generalized, but the atypical cases that arise in the zone of the rule's over- and underinclusion.

Johnston's model, like those to be examined below, makes contestable assumptions about judicial information and learning; I will subsequently defend the plausibility of those assumptions. The point of emphasis here is that Johnston's model adapts, with appropriate modifications, to the interpretation of general statutory commands. Litigants whose activity falls within a new statute's text but not within some reasonable conception of its purpose - the person who quietly rides a bicycle through the park and is fined under the statute banning "vehicles"-will contest more cases than litigants whose activity is condemnable on both textual and purposive grounds. The judges will observe a sample of cases in which the text appears dramatically overinclusive (or underinclusive, although not in this example), and will shift towards standard-based interpretation involving venerable techniques of attributed legislative intent, avoidance of absurdity, canons favoring equitable and lenient interpretation, and so forth.

Over time, however, the picture will change. With increased frequency litigants will test the limits of interpretive flexibility, contesting cases in which the text clearly covers their activity and only a very narrow or grudging conception of purpose will support an exemption. The costs of overinclusion produced by rule-based interpretation will diminish - or so it appears from the sample of litigated cases-and at the margin judges will increasingly favor textual interpretation. In this way judges will oscillate between rule-like and standard-like interpretations.

\section{Cycling over sources.}

The engine that drives rules-standards cycling is the effect, on the judges' information, of litigants' decisions about which cases to bring and which cases to settle-generally, "settlement effects." But that mechanism generalizes beyond the choice between rules and standards. Settlement effects might also explain cycling among different interpretive sources, even if all of the possible sources specify legal directives of the same (rule-like or standard-like) character. 
Consider a judge who conceives his aim as consulting interpretive sources for evidence of "legislative intent,", and suppose that in every litigated statutory case litigants automatically introduce all relevant portions of two sources that provide such evidence-call those sources statutory text and legislative history. The judge begins with the assumption or expectation that text provides the best evidence of legislative intent. Litigants aware of the judge's expectation will not pursue cases in which the text clearly favors one side or the other. The litigated cases will disproportionately be drawn from the subset of cases in which text is ambiguous or otherwise unhelpful. In some fraction of those textually obscure cases, however, the legislative history will provide unequivocal support for one party. The judge, observing only the stream of litigated cases, will observe that text is always ambiguous while legislative history is at least sometimes helpful. The judge will revise his expectations, and will pronounce legislative history the better source.

As the judge starts to give paramount weight to legislative history, however, litigants will increasingly tend to settle out cases in which the legislative history clearly dictates a judgment for one side or the other. The cases remaining in the pool will be those in which the legislative history is equivocal-and some fraction of those cases will be clear cases as far as the text is concerned. If the judge revises his expectations once again, pronouncing text the better source, the upshot will be a cyclical reversal of judicial preferences over sources. To be sure, no real judge will ever entirely ignore text, and few real judges will entirely ignore legislative history. ${ }^{15}$ So cycling over sources will occur within a narrower band than the mechanism suggests; even when the court reaches the extreme points of the oscillation, it will pay some attention to the disfavored source. But those details do not affect the basic process at work.

\section{The scope of litigation mechanisms.}

How convincing are these settlement-based mechanisms? The easy transposition of Johnston's model from common law adjudication to statutory interpretation provides a clue that the mechanisms are excessively general. While Johnston aims to supply a model of rulesstandards cycling in tort law, nothing in the assumptions or boundary conditions of his informal model confines it to tort law, private law, or

14 I will ignore as irrelevant all of the standard problems about what, if anything, legislative "intent" means. For a discussion of this issue, see Daniel A. Farber and Philip P. Frickey, Law and Public Choice: A Critical Introduction 89-102 (Chicago 1991).

15 Even (some) textualists will consult legislative history to disconfirm a seemingly absurd result. See, for example, Green v Bock Laundry, 490 US 504, 527 (1989) (Scalia concurring). 
any other domain. Johnston has actually sketched a perfectly general mechanism of rules-standards cycling that might, in principle, apply to any field of adjudication. The problem is that, in many fields, the law's choices about the form of legal directives - the decision on the rulesstandards question - have persisted for a long time and show no signs of chronic instability. Even accepting Johnston's empirical claim that some tort doctrines display continual cycling over rules and standards, some further domain restriction of the rules-standards cycling mechanism is necessary. Likewise, settlement effects should, on the analysis here, cause cycling over sources wherever there are multiple sources at play in adjudication, and those sources sometimes point in different directions. That condition holds not only in statutory interpretation, but also in the interpretation of other legal instruments (constitutions, contracts, and treaties) and in areas of common law adjudication where distinctive sources can be discerned in the mishmash of policy considerations and precedents that find favor with the judges. Yet many such areas display no obvious signs of cycling.

In sum, the general problem with cycling models rooted in litigation mechanisms is that such models are hard pressed to distinguish one domain of litigated cases from another. A useful account of interpretive change in the statutory domain, then, must attend to the distinctive conditions of statutory interpretation by incorporating an account of legislative behavior. ${ }^{16}$ The next section takes up this task.

\section{B. Legislative-Process Mechanisms}

1. Textualism, intentionalism, and self-fulfilling expectations.

A useful entry point into the dynamics of legislative and judicial expectations is an argument advanced by William Eskridge and John Ferejohn to criticize textualism. ${ }^{17}$ Textualists, they note, sometimes appeal to descriptions of the legislative process to support the basic textualist program of increasing judicial respect for the formalities of statutory text and decreasing judicial reliance upon legislative history.

16 Similar objections apply to Carol Rose's discussion of oscillation or cycling between crystals and mud-rules and standards - in property law. See Rose, 40 Stan L Rev at 580 (cited in note 5). Rose's model occupies a middle ground between the litigation mechanisms discussed in Part I.A and the legislative process mechanisms discussed in Part I.B. Rose's basic idea seems to be that legislatures or private contractors enact or agree upon crystalline rules, which courts then muddy up during the process of ex post adjudication, which brings about legislative reform that reinstitutes rules, which courts again convert to standards, and so forth. Obviously this cannot be a general explanation of cycling effects, let alone of doctrinal change generally; legislatures often enact standards while courts often announce and adhere to crystalline rules. But Rose has left the triggering or boundary conditions for her account unspecified, so its domain of relevance is wholly unclear.

17 See William N. Eskridge, Jr. and John Ferejohn, Politics, Interpretation, and the Rule of Law, in Ian Shapiro, ed, The Rule of Law: Nomos XXXVI 265, 265-94 (NYU 1994). 
One textualist claim, for example, is that legislative history is prepared by committee staff and goes unread by legislators deciding how to vote; another claim, not wholly consistent with the first, is that legislators not only attend to the content of legislative history but manipulate it by inserting material designed to mislead future interpreters about the terms of the legislative bargain.

Whatever the precise details of these textualist claims, Eskridge and Ferejohn point out that the textualist position may rest upon selffulfilling expectations and produce a self-sustaining equilibrium. Suppose that legislative coalitions anticipate the interpretive techniques that textualist judges will use. For concreteness, suppose that textualist judges will refuse to consult committee reports because they believe such reports to be written by committee staff without legislative supervision. Legislative coalitions, anticipating judicial behavior, will understand that the gains from inserting preferred language into committee reports are very low, and will therefore allow reports to be written by committee staff without supervision-precisely the outcome that textualist judges anticipate, but produced by legislative reaction to that very anticipation rather than by some exogenous cause.

Eskridge and Ferejohn do not claim that the self-fulfilling character of textualism is in itself objectionable. Their point is that legislative anticipation may support other self-sustaining equilibria besides the textualist one. Suppose that intentionalist judges believe that committee reports accurately reflect the legislative bargain. Then, on certain assumptions, legislators will have strong incentives to monitor the contents of committee reports, thereby ensuring that the reports do indeed reflect the bargain struck among the members of the majority coalition. The intentionalist expectation proves self-fulfilling as well. In related work, McNollgast has expanded upon the idea of a stable intentionalist equilibrium, arguing that legislators will empower other members - party leaders and committee chairs-as agents who will have reputational incentives to represent the enacting coalition's deal accurately and to suppress cheap talk by other members. ${ }^{18}$

None of this analysis claims that just any set of interpretive doctrines can produce a self-sustaining equilibrium. Eskridge and Ferejohn acknowledge that basic structural constraints on the Congress will limit the feasible set of equilibria that can be generated by judicial adoption of interpretive doctrines. A judicial decision to consult Ouija boards as an aid to statutory interpretation would not cause legislators to become experts in the occult, because legislators cannot control what the Ouija board will say. For present purposes, the important as-

18 See McNollgast, Positive Canons: The Role of Legislative Bargains in Statutory Interpretation, 80 Georgetown L J 705, 726 (1992). 
pect of the positive analysis of Eskridge, Ferejohn, and McNollgast is the basic assumption that the interaction between legislators and the judiciary is capable of generating at least some set of self-sustaining equilibria. Within the feasible set of stable equilibria, some will prove normatively superior on grounds of efficiency and distributive effects, so these sophisticated intentionalists suppose that the normative debate over interpretive conventions must proceed on those grounds.

\section{The possibility of self-defeating expectations.}

The Eskridge and Ferejohn analysis predicts that interpretive doctrines will remain stable over time, absent some exogenous change that destabilizes the doctrinal regime. ${ }^{19}$ A different starting point is the possibility that interpretive doctrines might, in some circumstances, rest upon self-defeating expectations rather than on self-fulfilling ones. To provide an introductory example, the idea of self-defeating expectations enables a very different analysis of the dynamics of textualism than the one that Eskridge and Ferejohn provide.

Whether or not Eskridge and Ferejohn are correct that the effect of textualism is to produce a self-enforcing equilibrium, a leading justification for textualism rests upon the opposite prediction: that judicial recourse to legislative history in search of an accurate record of legislative "intent" will prove self-defeating. On this view, legislators anticipating judicial use of legislative history will pollute the record with misleading snippets and colloquies designed to skew subsequent judicial decisionmaking, so that judges who treat legislative history as a valuable evidentiary source will have initiated a self-defeating causal process that makes legislative history a valueless source instead. ${ }^{20}$

Yet textualists who claim that treating legislative history as valuable renders it valueless should not overlook that the same problem may afflict their preferred interpretive approach. There is no particular reason to believe, a priori, that a textualist approach that eschews legislative history and emphasizes statutory text will create a selfsustaining equilibrium. To the contrary, both halves of the textualist program might prove self-defeating, given certain conditions. As for the textualist devaluation of legislative history, the dominance of textualist judges might so greatly reduce the expected benefit to legisla-

19 See Eskridge and Ferejohn, Politics, Interpretation, and the Rule of Law at 289-90 (cited in note 17$)$.

20 See, for example, Antonin Scalia, A Matter of Interpretation: Federal Courts and the Law 34 (Princeton 1997) (Amy Gutmann, ed) ("[T]he more courts have relied upon legislative history, the less worthy of reliance it has become."); Note, Why Learned Hand Would Never Consult Legislative History Today, 105 Harv L Rev 1005, 1012 (1992) ("[T] he widespread expectation that judges will consult legislative histories leads to [their] distortion ... and makes them unreliable indicators of congressional intent."). 
tors of manipulating legislative history that the history would become a more accurate and more useful interpretive source, in turn encouraging future judges to use it, at least until it again becomes corrupt. ${ }^{21}$ I shall discuss this possibility in greater detail in the next section. As for the textualist preference for the statutory language itself, an early discussion of interpretive instability claimed that textualist conventions, or at least literalist conventions (the two are not quite the same), prove self-defeating because they produce legislative reactions that undermine the expectations upon which the conventions are based. The discussion appears in a famous passage by Francis Lieber, a nineteenth-century commentator:

The British spirit of civil liberty, induced the English judges to adhere strictly to the law, to its exact expressions. This again induced the law-makers to be, in their phraseology, as explicit and minute as possible, which causes such a tautology and endless repetition in the statutes of that country, that even so eminent a statesman as Sir Robert Peel, declared in parliament, that he "contemplates no task with so much distaste, as the reading through an ordinary act of parliament." Men have at length found out, that little or nothing is gained by attempting to speak with absolute clearness, and endless specifications, but that human speech is the clearer, the less we endeavor to supply by words and specifications, that interpretation which common sense must give to human words. ${ }^{22}$

The process that Lieber attempts to describe here is not wholly clear. On one interpretation, the British judges adopted a literalist interpretive stance designed to increase statutory clarity. (The motivation, on this account, seems to have been that statutory clarity would promote "civil liberty"-a notice-based concern of the sort that underpins some accounts of the void for vagueness doctrine and the rule of lenity. ${ }^{23}$ ) Yet the strategy proved self-defeating: Parliament responded by increasing the level of statutory detail to such a degree that statutes became incomprehensible-a form of information overload. If judicial literalism produces continually increasing statutory de-

21 See A. Raymond Randolph, Dictionaries, Plain Meaning, and Context in Statutory Interpretation, 17 Harv J L \& Pub Pol 71,75 (1993) (claiming that "[t] he [textualist] theory [ ] contains the seeds of its own destruction" and "encourages the distressing tendency of legal doctrine to oscillate from one extreme to the other over time").

22 Francis Lieber, Legal and Political Hermeneutics, or, Principles of Interpretation and Construction in Law and Politics, with Remarks on Precedents and Authorities 30 (Little and Brown 1839).

23 See Cass R. Sunstein, Nondelegation Canons, 67 U Chi L Rev 315, 332 (2000) ("The rule of lenity is inspired by the due process constraint on conviction pursuant to open-ended or vague statutes."). 
tail, and increasing statutory detail eventually decreases clarity so greatly that statutes become incomprehensible, then literalism is selfdefeating past the point of decreasing clarity. Even this description of the process leaves the central causal mechanism undescribed; it is unclear why Parliament responded to the judges' strategy by enacting an excessive and continually increasing level of statutory detail, rather than stabilizing at an optimal level. Despite the lacunae in Lieber's account, however, his analysis is an important early recognition that text-oriented conventions may produce self-defeating effects rather than self-enforcing equilibria.

\section{Cycling mechanisms and the legislative process.}

Under what assumptions would the formation of expectations by legislators and judges prove reciprocally self-defeating, and thus produce an interpretive cycle? I will illustrate the cycling mechanism with an extremely sparse and purposefully unrealistic informal model, and then add complexity and institutional detail to enrich the analysis by successive approximation. My concern is not to show that cycling must or probably will occur; as in most analysis that takes account of the reciprocal expectations of social actors, a range of outcomes is possible, and everything turns on the precise specification of rules and payoffs. My concern is just to show that cycling can occur under a reasonable approximation of the interpretive system.

Consider a simplified interpretive system with the following characteristics: there is a unicameral legislature that enacts statutory text by simple majority vote, with no executive veto of bills; and there is only one court, staffed by a single judge, ${ }^{24}$ whose sole objective is to ascertain as accurately as possible the policy compromise ${ }^{25}$ reached by

24 Subsequently I shall relax this assumption in order to consider whether cycling can occur with a multi-judge court. See Part I.C.2.

25 By "compromise" I refer to the standard spatial model in which legislators have preferences about the issue under consideration that can be portrayed along a single dimension, from ardent opposition to minimal support to ardent support, with the compromise being reached at a point along that continuum that gains sufficient support from both moderates and ardent supporters to ensure enactment. See McNollgast, 80 Georgetown $L J$ at 711-12, 721-25 (cited in note 18) (describing the process by which enacting coalitions reach legislative bargains). The precise location of the compromise point depends upon a variety of institutional details, such as the presence or absence of committees and the rules governing floor amendments. In a simple unicameral legislature with no committees, the compromise point will always converge upon the position of the median member of the whole chamber. With committees that possess agenda-setting power, the location of the compromise will depend upon whether a committee's proposal can be amended on the floor or is subject only to an up-or-down vote. See Kenneth A. Shepsle and Mark S. Bonchek, Analyzing Politics: Rationality, Behavior, and Institutions 115-29 (W.W. Norton 1997) (examining the spatial equilibria of pure majority, closed-rule, and open-rule amendment regimes). Many other parameters can be specified as well, but further elaboration would not contribute to my enterprise here. 
the members of the enacting coalition. This simple model attempts to capture McNollgast's insight that there is a critical collective action problem among the members of an enacting legislative coalition, and that this collective action problem fundamentally shapes the creation of statutory text and legislative history. ${ }^{26}$ Given some range of disagreement over the preferred policy among members of the enacting coalition, each member will have an incentive to attempt to move judicial outcomes toward her preference by manipulating legislative history or, less frequently, statutory text. The collective action problem arises because each member of the enacting coalition would prefer a system in which no member engages in opportunistic behavior to one in which all members do so, even if the first-best outcome for each member would be to behave strategically while others remain sincere. The intuition here is that unchecked opportunism hurts all members of the enacting coalition, who must all spend time and political capital either to engage in self-protection against strategic behavior or to engage in strategic behavior themselves. Moreover, an excess of opportunistic behavior blurs the lines of legislative compromise and makes interpreting courts more likely to misunderstand the legislative compromise.

Against this background, the critical determinants of cycling are (1) the information held by legislators and judges about the behavior of other actors, and (2) legislators' and judges' ability to learn. I will proceed by starting with the simplest case and successively introducing more realistic assumptions.

Suppose first that in each round the following sequence occurs:

(1) The legislature enacts a statute that is accompanied by legislative history.

(2) Each member of the enacting coalition (for short, "member") must choose one of the following two moves: (a) "manipulate the legislative history" or (b) "do not manipulate the legislative history." There is some positive cost to manipulation.

26 See McNollgast, 80 Georgetown L J at 716-17 (cited in note 18); Elizabeth Garrett, The Congressional Budget Process: Strengthening the Party-in-Government, 100 Colum L Rev 702 (2000) (explaining procedural constraints chosen by legislators as responses to collective action problems within congressional coalitions).

27 That members make their choices simultaneously is a reasonably realistic assumption. While members might prefer to wait until other members have played, in order to tailor their responses to the other members' actions, that behavior threatens to unravel the process because it has no natural stopping point; members might even wait until after a bill is enacted and retroactively insert strategically favorable "history." Accordingly, Congress itself attempted to discourage this behavior in 1978 by establishing the "bullet" convention: statements not delivered on the 
The court interprets the statute, reading both the text and the legislative history. In any case, the court will either "follow" or "discount" the legislative history, making its choice according to the following rules:

(a) If no member has chosen to manipulate, then the court follows the legislative history, determines the compromise reached by the enacting coalition with perfect accuracy, and interprets the statute accordingly.

(b) If one member has chosen to manipulate and no other member has, then the court is fooled, follows the manipulated legislative history, and interprets the statute in accordance with the preferences of the manipulating member, rather than in accordance with the enacting coalition's compromise.

floor during debate on a bill, but subsequently introduced into the Congressional Record, are preceded in the record by the symbol "•". See Edward O. Correia, A Legislative Conception of Legislative Supremacy, 42 Case W Res L Rev 1129, 1153 n 85 (1992) (noting that the bullet convention is one of several elaborate steps taken by Congress to document its own proceedings). Legislators who anticipate that later interpreters will know of the bullet convention and discount bulleted statements will have incentives to produce contemporaneous legislative history. Although the bullet convention can be partially circumvented by delivering partial remarks before passage and amending them after the fact, see id, a similar penalty on late movers is imposed by the judicial canon of construction that says courts will heavily discount legislative history created after enactment. See, for example, Consumer Product Safety Commission v GTE Sylvania, Inc, 447 US 102,117-18 (1980) ("[T]he views of a subsequent Congress form a hazardous basis for inferring the intent of an earlier one."), quoting United States v Price, 361 US 304, 313 (1960) (Douglas dissenting). These conventions place an end point on legislative maneuvering and thus compress the creation of history into a shorter span.

28 "Manipulation" means any action that attempts to deceive subsequent interpreters about the location of the point of compromise that the enacting coalition reached, along the onedimensional array of legislators' policy preferences in the standard spatial model. See note 25 .

29 It is surprisingly realistic to ignore intermediate rules. Two such rules are the "plain meaning rule," under which courts claim to consult legislative history only if text is ambiguous, and the "hierarchy of legislative history sources," under which courts claim to restrict themselves to certain sources of legislative history thought to be especially authoritative. As I have discussed elsewhere, these intermediate rules have proven highly unstable over the course of the Supreme Court's history, for there are several mechanisms that press judges towards the extremes-either unrestricted use or complete prohibition of legislative history. See Adrian Vermeule, Legislative History and the Limits of Judicial Competence: The Untold Story of Holy Trinity Church, 50 Stan L Rev 1833, 1880-83 (1998). One such mechanism is Eskridge's observation that courts that sample one item of legislative history soon find themselves compelled to consume all the history offered, because of the possibility that the first item incorrectly represents the majority coalition's deal. Another mechanism is that courts must respond both to the arguments of counsel, who have powerful incentives to discuss the legislative history even in cases they would win under the plain meaning rule, and to the arguments of dissenting colleagues. 
(c) If more than one member has chosen to manipulate, then the court detects the manipulation, discounts the manipulated legislative history, and attends solely to the statutory text. In this case the court will mistake the enacting coalition's compromise in some cases. (Note that conditions (3)(a)-(3)(c) specify the basic collective action problem: the enacting coalition as a whole is better off if no member plays manipulate than if all do, but each member does best if she is the only one to manipulate.)

(4) Members know whether the court followed or discounted the legislative history in the preceding round (but only in that round), and expect the court to play identically in the next round.

(5) Each member believes that all other members choose "do not manipulate" in every round.

(6) The gain to a member who successfully manipulates is greater than the cost of manipulation, but there is no gain (and thus a net loss) from unsuccessful manipulation.

In this version, the legislators and the court have partial information, and their ability to learn is restricted. All players are imperfectly or boundedly rational; they are not good Bayesians, because they do not fully update their expectations to take account of the past behavior of other players. ${ }^{30}$ I will subsequently vary the specifications to incorporate more robust learning by all concerned, but at every stage I retain the assumption of bounded rationality. I defend that assumption in Part I.D below.

Given the initial specifications, it is easy to see that a cyclical sequence results. All members will play manipulate if, but only if, the

30 More technically, games of incomplete information are usually solved under the assumption that the players reach a "perfect Bayesian equilibrium." That solution concept requires both that players take the best action in light of the available information, and that players correctly update their beliefs in light of their observations (where "correctly" means according to Bayes's rule). Avinash Dixit and Susan Skeath, Games of Strategy 419 (W.W. Norton 1999). See also Douglas G. Baird, Robert H. Gertner, and Randal C. Picker, Game Theory and the Law 83-84 (Harvard 1994) (discussing Bayesian game theoretic applications). The specifications given here violate the latter condition. Of course the perfect Bayesian equilibrium is a modelling assumption that, like all other modelling assumptions, varies in realism and utility across cases. The empirical evidence on whether people update their beliefs in Bayesian fashion is mixed. See Douglas D. Davis and Charles A. Holt, Experimental Economics 479-82 (Princeton 1995) (describing two controlled experiments that reach differing conclusions about whether people behave as Bayesians). 
court followed legislative history in the preceding round. In some Round $r$, the legislature will enact a statute, all members will play manipulate, and the court will discount the legislative history. In Round $r+1$, the legislature enacts a statute, no members play manipulate (because manipulation is costly and each member now believes that manipulation will prove fruitless), and the court follows the legislative history. Round $r+2$ is identical to Round $r$, and so on. The cycling occurs because the members of the enacting coalition always expect the court to behave as it did in the last period and do not expect other members to play strategically. These features cause the members to form expectations about the behavior of the court and their fellow members that prove self-negating in every round of play.

A few qualifications are in order. First, I have used the dynamics of legislative history to illustrate the cycling effect merely because that is a principal focus of debate in the literature. There is a similar possibility that self-defeating expectations may form around statutory text; that was Lieber's point about the effect of the literalism of the English courts. ${ }^{31}$ There are famous examples of manipulation of statutory text by members of the enacting coalition. ${ }^{32}$ The gains to the enacting coalition from enacting statutory text are usually higher than the gains from creating legislative history, so the enacting coalitions' incentives to monitor text will be more powerful and therefore the costs to particular members of manipulating text will be higher. But it is also true that particular members will gain more from manipulating text rather than history; the net effect on the incidence of textual manipulation is unclear.

Second, even if legislators create legislative history for reasons other than influencing judicial interpretation-influencing agency interpretation and impressing constituents are other possible aims - that will merely affect the base level of legislative history that is produced; cyclical fluctuation above that base level might still occur. Untangling legislators' motives for creating legislative history is unprofitable and often impossible, for legislators create legislative history with a view both to instructing agencies and to directing the courts to monitor the agencies' compliance upon subsequent judicial review. ${ }^{33}$

Third, the mechanism described above assumes that the court instantly interprets enacted statutes. In the real world, the time lag be-

31 See Lieber, Legal and Political Hermeneutics at 30 (cited in note 22).

32 A famous, albeit controversial, example of textual manipulation is described in William N. Eskridge, Jr. and Philip P. Frickey, Cases and Materials on Legislation: Statutes and the Creation of Public Policy 752-58 (West 2d ed 1995), discussing In re Sinclair, 870 F2d 1340 (7th Cir 1989).

33 These complexities are discussed in Peter L. Strauss, When the Judge is Not the Primary Official with Responsibility to Read: Agency Interpretation and the Problem of Legislative History, 66 Chi Kent L Rev 321 (1990). 
tween enactment and interpretation might make it more difficult for legislators and courts to form reciprocal expectations. Note that nothing important changes if the lag is constant; the mutual adjustment of expectations will simply be delayed by a period equivalent to the lag. If, however, the lag is random, so that any particular statutory case is equally likely to call for the interpretation of a statute enacted a century ago and one enacted a decade ago, then it might be impossible for courts to draw (even limited) inferences from the stream of cases they see. But random lag is hardly a plausible picture of how the interpretive system works. At the Supreme Court level at least, most new statutory cases arise under relatively recent statutes receiving their first layer of judicial gloss. In the 1998 Term, the Court issued a package of important decisions that began to fill in the laconic text of the Americans with Disabilities Act of $1991 .^{34}$ There is no chance that the next term will see an equally foundational interpretation of the Judiciary Act of 1789 . Over time, a statute's meaning is increasingly fixed by accumulating layers of precedent, and there is a diminishing flow of new cases arising under old enactments. So the assumption of instant interpretation is a reasonable simplification. In general, each of these three qualifications makes it more costly for actors to predict other actors' behavior and more difficult for observers to determine whether cycling actually occurs, but this is just to say that there is noise in the interpretive system. Relaxing the contrary assumptions of the model would add complexity for little analytic gain.

A more serious objection is that the cycling mechanism described here makes very restrictive assumptions about legislative and judicial capabilities. But the cycling effect persists even if those assumptions are relaxed in some directions and to some degree. Note that, as initially specified, the court does not learn at all-it follows the same mechanical decision rule in every round. What if the court itself decides whether to follow or discount legislative history based upon the members' behavior in the last round? Condition 3 above has to be modified. Suppose that the court behaves as originally specified in the first round. Subsequently, however, the court plays discount either if (1) more than one member played manipulate in the previous round or (2) more than one member plays manipulate in the present round. The court plays follow if neither condition is met. The intuition here is just that the court learns, albeit imperfectly, and mistrusts the legislative record until members have not manipulated it for some time.

These changes merely change the period of the cycle. Suppose that at the start of play, members expect the court to follow legislative

34 See Sutton v United Airlines, Inc, 527 US 471 (1999) (glossing statutory definition of disability); Murphy $v$ United Parcel Service, Inc, 527 US 516 (1999) (same). 
history (nothing turns on this supposition - the same pattern emerges, with slightly altered timing, if the members' initial expectation is that the court will discount legislative history). All members will play manipulate in Round 1; the court (following Condition 3) will detect the manipulation and play discount. In Round 2 the members do not manipulate (because the court played discount in Round 1) and the court will again play discount (because the members played manipulate in the last round). In Round 3 the members do not manipulate (because the court played discount in Round 2) and the court plays follow. In Round 4 the members all play manipulate and the court plays discount. In Round 5 the members do not manipulate and the court plays discount. The sequence continues with a cyclical pattern of two discounts and one follow. Different specifications of the court's precise learning abilities and decision rules will yield different results, but it is clear that cycling can occur under some range of reciprocal legislative and judicial expectations even if all players change their behavior in response to others' behavior.

Another restrictive assumption is that the members of the enacting coalition all assume that no other member engages in strategic behavior. Here too, however, cycling may persist even if the assumption is relaxed. Suppose that, with the original conditions of judicial learning reinstated, Condition 5 above is modified to say that each member believes all other members will play in the next round whatever they played in the last round. If in some Round $r$ all members played manipulate and the court played discount, then in Round $r+1$ no member will play manipulate (each thinks all the others will play manipulate, so each calculates that there is no point in incurring the costs of manipulation) and the court will play follow. In Round $r+2$ each member plays manipulate, calculating that none of the others will do so, and the court plays discount. The cycle continues, even though members have become aware of others' capacity for manipulation, because each member falsely believes she can outwit everyone else.

Even in this version, members are only half-cunning: each member believes that she alone has special insight into the strategic situation, overlooking that everyone else has access to the same information. The hardest question is whether cycling occurs if members become aware of their common knowledge-if all members become aware that all are aware of the strategic situation and the resultant collective action problem. Even with common knowledge, cycling will occur so long as each member plays manipulate whenever the court has played follow in the preceding round, just as the members did under the supposition that each member thought that she alone would play manipulate. Each member will indeed play manipulate if she reasons, according to the standard logic of collective action problems, that 
manipulation is a dominant strategy - that it is her best response to any possible choice by other members."

As in all collective action situations, however, there are other possibilities. Members might develop reputational sanctions or centralized enforcement institutions sufficient to change each member's payoffs to the point where sustained cooperation - that is, forbearance from manipulation of legislative history-occurs. It is hard to say anything very general about whether such institutions will arise. The leading empirical study of such situations suggests that repeated interaction in collective action situations produces a wide range of outcomes, along a spectrum from continual defection and noncooperation to full cooperation secured by reputational norms or centralized enforcement. Which outcome is most probable depends upon a myriad of factors, such as the precise payoff schedules, the number of players, the nature of communication among the players, and so on.

As for Congress in particular, the most prominent suggestion in the literature is that legislators can create delegates empowered to speak authoritatively for the compromise within the enacting coalition and to suppress, or at least reduce, manipulation by other members of the coalition by means of threats and sanctions (the allocation of committee assignments, campaign funds, and so forth). This possibility underpins Eskridge and Ferejohn's view that "legislative intent" can be modeled as a self-enforcing equilibrium - one in which courts consult legislative history and legislators, aware that courts will do so, empower delegates such as party leaders and committee chairs to police manipulation and monitor the legislative history to ensure that it accurately reflects the compromise within the enacting coalition. ${ }^{37}$ Likewise, McNollgast suggests that the enacting coalition will empower delegates-most notably floor managers and bill sponsors-who will have reputational incentives to represent accurately the coalition's deal. ${ }^{38}$ As repeat players, those delegates will incur reputational penalties for engaging in manipulation that moves the apparent tenor of the legislative history away from the coalition's agreement and toward their private preferences.

Maybe all this is so, and maybe it isn't. Empowering delegates to police manipulation and to render authoritative descriptions of the deal is an application of the standard centralization strategy for over-

35 See James D. Morrow, Game Theory for Political Scientists 77-79 (Princeton 1994) (defining dominant strategies in prisoner's dilemma games).

36 See Elinor Ostrom, Governing the Commons: The Evolution of Institutions for Collective Action ch 1 (Cambridge 1990).

37 Eskridge and Ferejohn, Politics, Interpretation, and the Rule of Law at 275 (cited in note 17).

38 McNollgast, 80 Georgetown $\mathrm{L} J$ at 726 (cited in note 18). 
coming conflict in collective action situations. Yet here as elsewhere the centralization strategy in turn produces an agency problem: $:^{39}$ the agents empowered to monitor and to represent deals will have preferences of their own, perhaps preferences far removed from the compromise within the enacting coalition (consider the protracted and inconclusive debate about whether congressional committees have extreme preferences due to self-selection ${ }^{40}$ ). So the gain to the coalition's agents from manipulating legislative history or engaging in other strategic action may -in some domains will-outweigh the reputational penalties incurred, even assuming the manipulation is detected. As an important critique of $\mathrm{McNollgast} \mathrm{notes:}$

The temptation for a windfall opportunity may be worth, in any given circumstance, the degradation in value of the spokesperson's future dealings, especially when discounted by time, likelihood of detection, and probability of sanction. The temptation is especially great for those who intend to move on to higher office or to retirement, for example."

This captures the incentives of the delegates, but another point is that from the standpoint of the delegators the detection and sanctioning of agents who engage in self-interested behavior itself presents a secondorder collective action problem. Assuming that those who detect and sanction wayward delegates incur some cost for doing so, either directly or in foregone opportunities for future cooperation with the delegates, members will free ride on the sanctioning efforts of other members, and sanctions will be underproduced. This is just an instance of a standard problem about how self-enforcing systems of sanctions ever get off the ground in collective action situations.

All in all, then, the possibility remains that the collective action problem among legislators, combined with restricted information and learning on the part of both legislators and judges, will not produce a set of interpretive conventions that are self-enforcing in equilibrium, but rather will generate self-defeating expectations and a continual cycle of mutual adjustment. To be sure, cycling is only one possible (dis)equilibrium of the interpretive system; whether the system will

39 Geoffrey A. Brennan and Alan Hamlin, Democratic Devices and Desires 36-40 (Cambridge 1999) (describing the problem of exploitation inherent in agency).

40 Three positions are debated in the literature. One holds that committees are composed of self-selected members with extreme preferences; another denies that view; a third holds that committees tend to hold preferences opposite to that of the executive. For overviews, see David Epstein and Sharyn O'Halloran, Delegating Powers: A Transaction Cost Politics Approach to Policy Making under Separate Powers (Cambridge 1999); Forrest Maltzman, Competing Principals: Committees, Parties, and the Organization of Congress (Michigan 1997).

41 Miriam R. Jorgensen and Kenneth A. Shepsle, A Comment on the Positive Canons Project, 57 L \& Contemp Probs 43, 47 (1994). 
converge to a stable equilibrium depends upon a precise specification of conditions, and at present we lack sufficiently detailed knowledge of those conditions to rule in or rule out the most critical possibilities. Subsequently, I will present some empirical fragments to the effect that the pattern of interpretive doctrine over time is at least compatible with a cycling hypothesis, but even that weak claim presses against the limits of our current knowledge.

\section{Cycling and Judicial Structure}

The cycling mechanisms discussed so far have assumed a court staffed by a single judge. This is a conventional assumption in the small literature that applies cycling models to legal problems, ${ }^{42}$ and more generally in the literature on change or evolution in legal rules. The assumption is in part defensible on standard methodological grounds as a device for making cycling models tractable; introducing institutional detail such as multiple-judge courts may add complexity that does little to improve the analysis. Yet a bit more must be said, because, on certain assumptions, a collective judiciary might prove less susceptible to doctrinal cycling than a single judge, in which case the assumption is not only simplifying but also distorting. The problem comes in two versions: the existence of multiple coordinate courts and the presence of multiple judges on a single court.

\section{Multiple coordinate courts.}

The existence of multiple coordinate courts might dampen cycling, or more precisely the appearance of cycling, purely by the effect of aggregating the cycles that affect individual judges. Suppose that a court staffed by one judge must decide what weight to give to a certain canon of construction, where the canon may take one of three weights: 1,2 , or 3 (we can interpret these weights as a strong clear statement rule, a balancing factor, or a weak tiebreaker). On the mechanisms discussed above, a single judge might continually cycle through the three different versions of the canon.

To consider only litigation mechanisms, suppose that at the starting point of the cycle precedent indicates that the canon is to have weight 1 . Settlement effects might cause litigants to litigate only cases in which the canon does not cut sharply in one party's favor; the judge will progressively believe the canon is less and less helpful, and downgrade its weight from 1 to 2 to 3 . Eventually a tipping point is reached at which litigants bring a set of cases in which the canon would, if

42 See notes 4-5 (collecting references).

43 See, for example, Gillian K. Hadfield, Bias in the Evolution of Legal Rules, 80 Georgetown L J 583, 586 (1992). 
given strong weight, prove easily dispositive; so the judge starts to upgrade the canon again, until the cycle repeats.

Now suppose a jurisdiction in which there are three coordinate district courts each staffed by a single judge, with no appellate review. (If this sounds odd, it is akin to the structure of criminal adjudication in the federal system before $1889 .^{44}$ ) Each court will progress through the cycle, but there is no reason to think that the aggregate pattern of decisions will cycle. If each court begins the cycle at a different point, for example, each court may progress from 1 to 2 to 3 while the composition of the overall pool of decisions remains unchanged: a third of the cases will involve assigning the canon weight 1 , another third weight 2 , and the final third weight 3 . Thus a treatise indiscriminately collecting interpretive decisions across coordinate jurisdictions might reveal conflicting canons, but would not reveal the existence of intrajurisdictional interpretive cycles. Aggregation smooths out the instability present in each jurisdiction taken separately.

\section{Collective appellate courts.}

Introducing centralized appellate review into the system will eliminate the dampening effect of multiple courts, ${ }^{45}$ and thus tends to reinstate doctrinal cycles. If the appellate court is itself staffed by multiple judges, however, a different effect will occur. Here we must distinguish two senses of "cycling." In the first sense, cycling refers to doctrinal oscillation. In the second sense, cycling refers to voting cycles that can arise in multimember decisionmaking bodies. ${ }^{46} \mathrm{~A}$ voting cycle is one possible outcome of the standard voting paradox that arises under simple majority rule when there are at least three possible choices. Suppose the court is composed of three judges $(1,2$, and 3$)$, there are three possible legal rules under consideration $(A, B$, and $C)$, and there are no restrictions on the reintroduction of defeated proposals. The preference rankings are Judge $1(A>B>C)$; Judge $2(C>A>B)$; and Judge $3(B>C>A)$, reading " $X>Y$ " as "prefers $X$ to $Y$." If the first vote is between $A$ and $B$, a majority of the judges will vote for $A$. In the next vote, between $A$ and $C$, a majority prefers $C$. In the next vote,

44 See Richard H. Fallon, Daniel J. Meltzer, and David L. Shapiro, Hart and Wechsler's The Federal Courts and the Federal System 1636 \& n 3 (Foundation 4th ed 1996) (describing limitations on Supreme Court review of federal criminal judgments before 1889).

45 At least this is true for any particular system with a unified judicial hierarchy, such as the federal system. It may not be true if cycles are aggregated over different jurisdictions, such as states.

46 For an explanation of voting cycles, and the effects of parliamentary rules designed to prevent their occurrence, see Saul Levmore, Parliamentary Law, Majority Decisionmaking, and the Voting Paradox, 75 Va L Rev 971 (1989). For an overview of the massive literature on the connections among voting cycles, the legislative process, and Arrow's Theorem, see Farber and Frickey, Law and Public Choice at 38-62 (cited in note 14). 
between $C$ and $B$, a majority prefers $B$, which then loses to $A$, and so on. A voting cycle is in progress. The court's choices are intransitive, meaning that the court prefers $A$ to $B, B$ to $C$, and $C$ to $A$. If we equate intransitivity with irrationality, then the aggregation of preferences held by individually rational voters has produced a set of choices that are irrational at the group level.

There are complex interactions between voting cycles and the mechanisms of doctrinal cycling sketched previously. It is possible that voting cycles might dilute doctrinal cycles. At the limit, uncontrolled voting cycles on a multimember court might produce a thoroughly chaotic and incoherent stream of outcomes without any discernible pattern. Of course actual courts never reach that limit, but the strategies those institutions develop to suppress voting cycles will have complicated, and probably crosscutting, effects on doctrinal cycles.

Multimember institutions exposed to voting cycles develop institutional structures that dampen voting cycles by creating "structureinduced equilibrium.", I shall focus upon the most important such structure (for courts, anyway): a norm of stare decisis, or following precedent. Stare decisis dampens voting cycles by preventing judicial reconsideration of prior decisions. ${ }^{48}$ If, in the previous example, the court has cycled through the choices once, stare decisis will preclude reconsideration of the previously defeated options, even if one of those options would defeat the current rule.

47 See Kenneth A. Shepsle and Barry R. Weingast, Structure-Induced Equilibrium and Legislative Choice, 37 Pub Choice 503, 503-19 (1981) (arguing that institutional mechanisms may prevent cycling).

48 See Maxwell L. Stearns, Standing Back from the Forest: Justiciability and Social Choice, 83 Cal L Rev 1309, 1314-15 (1995) (noting that stare decisis stops cycling by barring motions to reconsider).

49 Another effect of stare decisis is to produce path dependence, meaning that the order in which cases arise determines how they will be decided. See Frank H. Easterbrook, Ways of Criticizing the Court, 95 Harv L Rev 802, 817-19 (1982). Path dependence gives power to agendasetters, litigants, and judges who can influence the docketing of cases and the assignment of opinions. (On the Supreme Court, the Chief Justice schedules cases and assigns opinions when in the majority, while the Rule of Four allows any four Justices to influence the Court's agenda by forcing a grant of certiorari. See Maxwell L. Stearns, The Misguided Renaissance of Public Choice Theory, 103 Yale L J 1219, 1281 (1994)). Here I shall ignore the question of how the judicial agenda over interpretive decisions is set. I do so because the opportunity to influence agendas is far more valuable with respect to substantive rules than with respect to the interpretive rules discussed here (which means in turn that agenda-setters will devote fewer resources to manipulating the ordering of interpretive decisions). To some extent, interpretive rules are neutral as across substantive controversies, in the weak sense that agenda-setters will often be unable to predict whether one rule or another will better favor their future interests. The canon "interpret statutes to avoid constitutional questions," for example, will in future cases sometimes favor and sometimes disfavor the agenda-setter's substantive policy interests, so the agenda-setter will devote more resources to influencing substantive decisions whose policy valence is immediately discernible. 
Stare decisis should have crosscutting effects on doctrinal cycling. On one hand, very strong precedent might tend to lengthen the periods of a doctrinal cycle. If precedents squarely hold that legislative history is admissible, then a subsequent court will be more reluctant to move to the position that legislative history should be excluded from the interpretive process, even if the stream of cases that the judges currently observe suggests that exclusion would prove beneficial. Stare decisis requires judges to pay some price (in political capital and perhaps individual reputation) in order to change a legal rule. Even as the perceived benefits of changing the rule grow, stare decisis will cause judges to postpone the change longer than they otherwise would. On the other hand, stare decisis increases the tendency of nonjudicial actors in the interpretive system to adjust their expectations in the manner previously described. The litigation mechanisms assume that litigants will settle cases that are easy in light of recent decisions, because litigants believe that judges will give weight to the doctrinal propositions established by those decisions. A rule of stare decisis encourages that belief. The legislative-process mechanisms, likewise, posit that legislators believe that courts will do in the next period what they did in the last, and stare decisis encourages that belief as well. So the effect of stare decisis on doctrinal cycles cuts in offsetting directions when courts treat precedent as weighty but not absolute, which is precisely how most courts treat precedent most of the time.

The presence of multiple judges has another major effect that should retard doctrinal cycles: assuming that judges are appointed at different times and have different lengths of tenure, some judges will be more experienced than others, and that experience may enable those judges to learn to avoid the cycling phenomenon. The next section takes up this possibility, but it reinforces the overall conclusion that the net effect of multimember courts on doctrinal cycling is unclear. In what follows, I shall assume that the distortion introduced by the assumption of a single-judge court is not so great as to render the exploration of doctrinal cycling mechanisms useless or uninteresting, an assumption that is justifiable only because there are crosscutting effects that can plausibly be assumed to wash out. It remains true that a better version of the model would account for the collective character of the judiciary, just as it accounts for the collective character of the legislature.

\section{Rational Expectations and Adaptive Learning}

The most serious challenge to the cycling mechanisms discussed here points to the assumptions about judicial expectations, information, and learning embedded in the models. Other applications of cycling mechanisms to law have elided this issue, but that procedure is 
hardly satisfying with respect to a mechanism's core premises. Yet the assumption of restricted judicial learning is certainly a defensible one.

Cycling mechanisms do not assume that judges are incapable of learning at all. Rather, they assume that judges learn from immediate past trends: if judges have been reading legislative history and legislators have been filling the history with obvious cheap talk, or if judges have been interpreting statutes to enact standards and litigants have been appealing cases in which rule-like interpretations would have improved outcomes, judges will learn from the stream of cases that have come before them and will adjust doctrine in light of that information. Yet judges do not learn in a higher sense; they do not correct for the biased sample of cases that litigants appeal, nor do they account for legislators' expectations about judicial behavior in forming their expectations about legislative behavior. In general, cycling mechanisms portray the actors in a cycle as incapable, to a greater or lesser degree, of appreciating that others' behavior is determined in reaction to the actors' own behavior, rather than simply by some innate preference or tendency.

There are two possible lines of critique of this approach, one broad and one narrow. The broad critique stems from the theory of rational expectations, ${ }^{51}$ which holds that the market will not form systematically erroneous expectations; any errors will be randomly distributed around the truth. In economics, the argument for this picture is simply that market actors who commit systematic errors will lose out to actors who do not, because market participants can profit by forming expectations that are accurate on average. Conversely, the analyst who claims that market actors commit systematic errors should be able to reap a handsome profit on her superior insight, yet if that were so, all professors of finance would be billionaires.

The cycling models presented here do assume that the judges commit systematic error; their expectations about the composition of the stream of cases, statutes, or legislative history systematically suppose that the next period will look more like the last period than it actually does. As such the cycling models assume a different model of learning - "adaptive" learning. ${ }^{52}$ Yet there is no particular reason to believe that judges, as opposed to market participants, will form fully rational expectations. The elaborate network of safeguards that surround the judicial office ensures that judges can rarely profit from any decision, let alone by correctly anticipating the future behavior of leg-

50 See Elster, Logic and Society at 112 (cited in note 4).

51 A good overview is Preston J. Miller, ed, The Rational Expectations Revolution (MIT 1994).

52 See Shaun Hargreaves Heap, et al, The Theory of Choice: A Critical Guide 310-11 (Blackwell 1992) (explaining adaptive learning theory). 
islators or litigants. Nor is there market discipline (or much in the way of bureaucratic discipline) imposed upon a judge who systematically makes predictive mistakes. Law professors may accurately diagnose systematic judicial errors without having the least ability to displace the judges in the way that new market entrants might displace systematically confused firms. In general the rational expectations thesis is an unlikely picture of judicial learning.

A narrower critique, however, would portray judges as at least capable of learning by optimal updating of their beliefs, given their observations-in which case judges could perceive the bias in the sample of litigated cases that come before them, or could learn over time that seemingly beneficial doctrinal adjustments will merely cause a renewed round of cycling. But the same factors that undermine the rational expectations critique make imperfect learning a more sensible starting point than the Bayesian position that social actors optimally update their beliefs in light of their observations. ${ }^{54}$ First, there are no direct rewards (or penalties) to judges who accurately update their beliefs (or fail to do so). Bayesian competence is a modeling assumption that makes the most sense for players with a substantial stake in the outcome of the game, and judges' stakes in the interpretive process are indirect at most. ${ }^{55}$ In the absence of incentives for alertly rational behavior, judges may come to the bench with a package of traditional nostrums and bromides about legislation that are updated adaptively - too slowly from the Bayesian standpoint-if indeed they are ever updated at all. Second, constitutional provisions, statutes, and the common law all put tight controls upon the information that judges receive through the litigation process; examples are

53 See Douglas G. Baird and Edward R. Morrison, Optimal Timing and Legal Decisionmaking: The Case of the Liquidation Decision in Bankruptcy, Chicago John M. Olin Law \& Economics Working Paper No. 86 (1999), available online at <http://papers.ssrn.com/paper.taf? abstract_id=187848> (visited Jan 12, 2001) (discussing effects of absence of market discipline on decisionmaking capacities of bankruptcy judges); Eric Talley, Precedential Cascades: An Appraisal, 73 S Cal L Rev 87, 89 (1999) (noting arguments that "judges (often by design) are more insulated from the inefficient consequences of their decisions than are analogous market participants").

54 For law and economics literature on the evolution of legal rules that assumes imperfect judicial learning, see, for example, Robert Cooter, Lewis Kornhauser, and David Lane, Liability Rules, Limited Information, and the Role of Precedent, 10 Bell J Econ 366 (1979) (assuming that courts are restricted to updating legal rules based on information from the cases they hear); Hadfield, 80 Georgetown L J at 585 (cited in note 43).

55 Compare Lawrence Baum, The Puzzle of Judicial Behavior 35 (Michigan 1997) (noting difficulty in predicting judicial behavior, given the absence of direct, tangible incentives affecting life-tenured judges). See also David W. Rohde and Harold J. Spaeth, Supreme Court Decision Making 72-74 (W.H. Freeman 1976) (noting that Justices' lack of electoral accountability, lack of ambition for higher office, and position as members of a court of last resort might render their behavior difficult to predict). 
the rules of standing, concreteness, and adversity, rules against ex parte contacts, restrictive doctrines of judicial notice, and so forth.

Apart from these abstractions, the determinants of judicial learning are in principle subject to empirical investigation. Two critical factors are (1) the rate at which cycling occurs, or the period of cycles, and (2) the average length of judicial tenures. If cycles occur very slowly, so that an average judge will observe only one or two doctrinal switches within the relevant set of alternatives during a career of average length, then the restrictive assumptions about judicial learning are a decent approximation. Under these conditions, there is no particular reason to suppose that judges will detect a slow cycling effect produced by long-term shifts in the expectations of the relevant actors. If, on the other hand, cycling occurs with great rapidity (perhaps because cycling is caused by settlement effects and the volume of litigated cases is very high, ${ }^{56}$ or because cycling is caused by legislative reactions to judicial behavior and legislators respond very quickly to the latest doctrinal trends), then judges should observe many oscillations and should come to adopt a more sophisticated form of adaptive learning than the simple form of (over)correction supposed by the cycling models. I shall subsequently say something about the period of cycles in the interpretation of general statutory commands and in the use of legislative history, both of which seem to oscillate rather slowly (over years or even decades rather than months). But that observation rests on very fragmentary data. In the absence of a great deal more information than we currently have, it is hard to assess the restrictive assumptions with any confidence. Surely, however, they are not so bizarre as to make the cycling mechanisms unworthy of exploration.

\section{CYCLING AND ITS COMPETITORS}

Whatever their abstract appeal, cycling mechanisms, and endogenous explanations for legal change more generally, possess virtues that are thrown into relief by comparison with the prevailing styles of exogenous explanation. This Part describes those virtues (and their accompanying vices), argues for a weak methodological preference for endogenous explanations, and discusses whether and how cycling mechanisms illuminate important topics in the history of interpretive doctrine.

\section{A. Exogenous and Endogenous Explanations}

The most venerable style of explanation ties interpretive change to broader trends in legal and intellectual history. William Blatt's ex- 
plication of the historical cycle between "equitable" and "strict" interpretation $^{57}$-in essence the rules-standards cycle in interpretive guise - is a sort of critical intellectual history of statutory interpretation, with explicit debts to Duncan Kennedy's analysis of the rulesstandards dialectic in the common law. ${ }^{58}$ Blatt, for example, seems to view the decline of the legal process-purposive approach to statutory interpretation since the 1960 s as a consequence of "[d]isenchantment with the legislative process $"$ "s9 on the part of judges and scholars, disenchantment partially grounded in public choice insights about the legislative role of interest groups.

Or consider the explanation of the decline of the legal process approach that is offered in the leading casebook on legislation authored by William Eskridge and Philip Frickey. ${ }^{60}$ The text explains the increasing prevalence of formal, text-oriented decisions in the 1970 s and 1980 s by reference to a combination of social and intellectual causes:

America after the mid-1960s was a different society, as consensus collapsed on fundamental issues of war, family and citizenship; economic growth faltered and oil price shocks introduced stagflation; and government came to be perceived as problematic, often even as a drain on society's productivity. These developments raised inevitable questions about statutory methodology. ${ }^{61}$

These social developments coincided with or caused - the account is ambiguous here-intellectual developments in public choice, social choice, and other areas that pressed federal judges towards a renewed attraction to formalist interpretation. ${ }^{62}$

This is a standard style of explanation in legal theory, at least before the recent infusion of political science, economics, and other methodologically pointed disciplines; a typical product of the approach is Grant Gilmore's The Ages of American Law. ${ }^{63}$ Obviously there are important questions here about the relative power of intellectual, social, and institutional explanations, questions I shall largely avoid. My narrow point is that on the standard criteria of theory choice-parsimony and simplicity of assumptions, comprehensive scope, and so forth - we should approach the question of interpretive

57 William S. Blatt, A History of Statutory Interpretation: A Study in Form and Substance, 6 Cardozo L Rev 799 (1985).

58 See Duncan Kennedy, Form and Substance in Private Law Adjudication, 89 Harv L Rev 1685 (1976).

59 Blatt, 6 Cardozo L Rev at 837 (cited in note 57).

60 See Eskridge and Frickey, Cases and Materials on Legislation at 562 (cited in note 32).

61 Id (emphasis added).

62 See id.

63 Grant Gilmore, The Ages of American Law (Yale 1977). 
change, and indeed doctrinal change generally, with a presumptive preference for endogenous explanations (such as the cycling mechanisms of Part I) over the exogenous explanatory style.

Eskridge and Frickey's explanation for the decline of legal process illustrates the plastic quality of exogenous explanations. ${ }^{64}$ If the resurgence of interpretive formalism had occurred in the 1950s and $1960 \mathrm{~s}$, the heyday of antiformalist legal process, rather than in the 1970 s, this sort of approach might explain it by reference to the strains of traditionalism and deference to authority detectable in the American cultural and polítical life of the period. The problem of excessive plasticity summarizes several distinct methodological sins that inhere in this style of explanation. First, the intellectual and social trends that the exogenous style takes as explanatory starting points are so abstract as to prove compatible with an extremely wide range of interpretive approaches and changes. ${ }^{65}$ Just as a large-scale theory of justice fails to dictate or even constrain one's views on diversity jurisdiction or the parol evidence rule, so too the factors to which the casebook points-decline of value consensus and skepticism about government - are as compatible with a preference for purposivism over textualism as with the opposite preference. ${ }^{6}$ Second, this style of explanation tends towards ad hoc explanations that are good for one case only. The multiplicity and complexity of society-wide political, economic, and intellectual trends in any era ensures that some facially plausible explanation of this sort can always be proffered to account for any particular doctrinal change. But this style offers no systematic attempt to identify causal mechanisms that operate with regularity across differing doctrinal contexts.

Roughly the same critique applies to the second major style of explanation for interpretive change that can be found in the literature: the family of positive political models that explain interpretive doctrine as a temporary policy equilibrium among lawmaking institu-

64 See Eskridge and Frickey, Cases and Materials on Legislation at 562 (cited in note 32).

65 Others have advanced a similar critique of attempts to explain the development of contract law by reference to the changing fortunes of laissez-faire political theory. See, for example, Richard A. Epstein, Contracts Small and Contracts Large: Contract Law through the Lens of Laissez-Faire, in F.H. Buckley, ed, The Fall and Rise of Freedom of Contract 25, 26-29 (Duke 1999).

66 Contrary to the casebook's assumptions, a libertarian will often favor purposive, rather than textual, interpretations of generally phrased statutes, because purposive interpretation will narrow the domain of governmental control. A recent example is Brogan v United States, 522 US 398 (1998), which posed the question of whether the facially unqualified terms of the federal false statement law, 18 USC $\S 1001$ (1988), covered a suspect's denial of wrongdoing-the "exculpatory no." Justice Scalia's majority opinion afforded the text its literal meaning and held that the denial constituted a false statement; the dissenters, emphasizing the statute's arguably narrower purposes, would have grafted an "exculpatory no" exception onto the text. 
tions. ${ }^{67}$ In these models, the Supreme Court (usually treated as a unified entity with a single utility function ${ }^{68}$ ) interprets statutes in the fashion that best promotes its policy preferences, with the critical constraint that its interpretation must take account of the anticipated reactions of other lawmaking institutions, particularly Congress and the President. The interaction between the players reaches a temporary equilibrium when no institution may shift the interpretation of a statute from the status quo point without being overridden by another institution.

Positive political models at least supply a succinct account of interpretive change: a change is an enduring departure from the interpretive status quo. As the circularity of this formulation makes clear, however, the positive political models do not speak to the question why such departures occur. Like the intellectual-history style of explanation, the positive political models provide no general theory of interpretive change. All change in these models results from exogenous disturbances that alter the interpretive equilibrium, such as a change in the composition of the Congress that allows the Court to move interpretive outcomes in its preferred direction without fear of an override. ${ }^{69}$ As nothing interestingly general can be said about which exogenous changes will cause which interpretive departures, positive political models may be conjoined with the same thoroughly ad hoc explanations that proliferate in the intellectual-history school. If the Supreme Court changes its interpretive stance, some political development or other can usually be found to provide explanatory fodder. To be sure, positive political models may be supplemented with (or, more accurately, may themselves be a supplement to) some broader theory of political change that yields interpretive consequences. But it is precisely the need for some broader account to which the positive political model must be appended that should create a methodological preference for the relative parsimony of endogenous explanations for interpretive change.

The endogenous cycling models canvassed in Part I fare quite well by comparison. One virtue of endogenous explanations is that they economize on information and assumptions. Cycling models advance a single form of explanation for every instance of interpretive

67 See, for example, William N. Eskridge, Jr. and Philip P. Frickey, Foreword: Law as Equilibrium, 108 Harv L Rev 26, 31-33 (1994); William N. Eskridge, Jr. and John Ferejohn, The Article I, Section 7 Game, 80 Georgetown L J 523 (1992).

68 See, for example, McNollgast, Politics and the Courts: A Positive Theory of Judicial Doctrine and the Rule of Law, $68 \mathrm{~S}$ Cal L Rev 1631, 1637-38 (1995) (proposing a sequential decisionmaking model that treats each federal institution "as if it were a single rational actor").

69 See id at 1633 (describing types of exogenous shock that may disturb political equilibria). 
change, one that does not need to be supplemented by ad hoc stories about particular exogenous shocks in order to account for every new departure from equilibrium. Nor do endogenous models need to be buttressed by some other large-scale theory that explains how the exogenous political or intellectual shocks are generated.

Another virtue of cycling models, and of endogenous explanations generally, is that they account for the felt experience of judges and lawyers more successfully than do their competitors. If almost all judges avow that they choose interpretive doctrines without regard to their policy preferences (and assuming preferences are not defined so capaciously as to include a preference for judging according to law), then a positive account of interpretive change must either discount the judges' avowals as cheap talk - the position to which the positive political models are committed-or else explain interpretive change without the postulate that judges act solely to advance their policy preferences. Cycling models adopt the latter strategy; they explain how it is that interpretive change might occur even with a single judge committed to the legal virtues of accuracy and fidelity.

The last and most important benefit of endogenous models of legal change is that they are relatively unexplored. Whatever their abstract virtues, the marginal intellectual return from developing such models is sure to be greater than the marginal return from adding the latest subtle filigree to the exogenous models that dominate the literature. Most people prefer to have three cookies and one glass of milk than to have four cookies.

To be sure, these methodological benefits have associated costs. First, the assumption of imperfect rationality and adaptive learning on the part of legislators and judges is more realistic but less precise than the standard rational expectations assumption that actors will avoid systematic error. Second, within reasonable bounds, a proponent of cycling models can avoid an embarrassing collision with the facts by tinkering with the period of the cycle; I will touch on that problem below. The argument here is just that these weaknesses of endogenous explanations are less serious, in light of the standard criteria of theory choice, than the weaknesses of the exogenously grounded competitors. That point supports a weak methodological preference for endogenous explanations, and cycling explanations represent a reasonable starting point within the class of endogenous explanations.

\section{B. Illustrations}

Any decent positive account must show that it can provide a reasonable purchase on the data, relative to its competitors, even if em- 
pirical verification is not the sole criterion of successful theory. ${ }^{70}$ The claim that interpretive doctrines cycle over time and within a range of positions is difficult to document, yet it corresponds to a casual empirical intuition widely held by scholars of legislation. "The history of Anglo-American statutory interpretation," Eskridge and Frickey write, "reveals a cyclical alternation between doctrinal rules that promise objectivity and certainty and equitable rules that promise justice and flexibility." Courts enamored with flexible interpretation in one period later become impressed with plain meaning and decline to interpret statutes flexibly, or to consult legislative history for indications of countertextual purpose. After some time the enthusiasm for plain meaning wanes and purposive interpretation based upon extrinsic sources becomes dominant, only to be displaced again by a renewed emphasis on text. Some canons of construction show cyclical trends: the courts use them as strong presumptions, then demote them to weak tiebreakers, and so on. ${ }^{2}$

I cannot hope to provide a full empirical consideration of the cycling phenomenon in interpretive doctrine because my competence as an empiricist is limited, our information is sparse, and the relevant empirical questions are intertwined with interpretive and evaluative questions of the sort that usually hamper empirical investigations of

70 See Daniel M. Hausman, Essays on Philosophy and Economic Methodology 70, 70-73 (Cambridge 1992).

71 William N. Eskridge, Jr. and Philip P. Frickey, Legislation Scholarship and Pedagogy in the Post-Legal Process Era, 48 U Pitt L Rev 691, 715 n 72 (1987). See also Mark L. Movsesian, Severability in Statutes and Contracts, $30 \mathrm{Ga}$ L Rev 41, $70 \mathrm{n} 184$ (1995) (noting that the popularity of the major interpretive approaches "ebbs and flows"); Michael Livingston, Congress, the Courts, and the Code: Legislative History and the Interpretation of Tax Statutes, 69 Tex L Rev 819, 823 (1991) (noting that "[t]he current debate over statutory interpretation is the latest installment in a longstanding controversy, one with a pronounced cyclical character"). But see Robert J. Martineau, Craft and Technique, Not Canons and Grand Theories: A Neo-Realist View of Statutory Construction, 62 Geo Wash L Rev 1, 1-3 (1993) (suggesting that the history of statutory construction does not fit either a cyclical or a nonrecurring pattern).

72 I shall omit extended discussion of the canons of statutory construction, principally because there are very few longitudinal studies tracing the history of particular canons. It is at least clear that some canons wax and wane in a cyclical fashion as the Court periodically inflates and deflates them. Consider the canon expressio unius est exclusio alterius - "to express one thing is to exclude another." Blatt, following Posner, explains that this maxim periodically disappears and reappears. See Blatt, 6 Cardozo L Rev at 799 n 2 (cited in note 57), citing Richard A. Posner, Statutory Interpretation-in the Classroom and in the Courtroom, $50 \mathrm{U}$ Chi L Rev 800, 813 (1983). A detailed study of the ejusdem generis canon in a single jurisdiction concludes that appellate courts alternately invoke and ignore the canon in a cyclical fashion. See R. Perry Sentell, Jr., The Canons of Construction in Georgia: "Anachronisms" in Action, $25 \mathrm{Ga} \mathrm{L} \mathrm{Rev} \mathrm{365,} \mathrm{404-05}$ (1991). But some canons do not seem to cycle; Lawrence Solan's study of the rule of lenity, for example, finds that the Court began to reduce the canon's weight around midcentury and has rarely taken it seriously since then, despite some minor perturbations as Justice Scalia and others have recently attempted to revive it. See Lawrence M. Solan, Law, Language, and Lenity, $40 \mathrm{Wm}$ \& Mary L Rev 57, 102-09 (1998). The overall picture is so murky that it is hard to say anything very useful at present. 
interpretive theory. ${ }^{73}$ s shall confine myself to impressionistic descriptions of two of the most critical areas of interpretive doctrine: the interpretation of general statutory commands and judicial resort to legislative history. The cycling explanation provides a strong account of the first, and a plausible, although incomplete, account of the second. In both areas the intellectual-history approach and the politicalequilibrium approach are hard pressed to account for the routine fluctuations that characterize the history of interpretive practice.

\section{General statutory commands.}

The most obvious cycle in interpretive doctrine occurs in the Supreme Court's treatment of general statutory commands - an ordinance stating "No vehicles in the park," for example. There is a widespread impression among scholars that, at the Supreme Court level anyway, judicial treatment of such cases oscillates between relative formality and relative nonformality, using formalism here just to mean rule-bound decisionmaking. ${ }^{74}$ Speaking only of this century, Holy Trinity's ${ }^{75}$ flexible treatment of a general statutory prohibition-based on arguments about legislative intent, legislative purpose, the absurdity of the statute's application to the case at hand, and background legal norms - was soon curtailed by the self-consciously literalist treatments of statutory language in Caminetti v United States, ${ }^{7}$ and, slightly later, in Crooks v Harrelson," both of which pronounced that clear statutory text is all-but-conclusive evidence of legislative intent.

But at the beginning of the Second World War the Court signaled a return to purposive interpretation, saturated by extrinsic sources, with the famous dictum of American Trucking Assocs" that "[w]hen aid to construction of the meaning of words, as used in the statute, is available, there certainly can be no rule of law which forbids its use, however clear the words may appear on superficial examination."," That basic attitude persisted through the Warren Court, which often tailored general commands to their background purposes. ${ }^{80}$ The Bur-

73 See Adrian Vermeule, Interpretive Choice, 75 NYU L Rev 74, 102 \& n 108 (2000) (describing the problems posed by empirical questions with evaluative predicates).

74 See Blatt, 6 Cardozo L Rev at 799-802 (cited in note 57) (discussing courts' alternation between the letter of the law and its spirit).

75 Church of the Holy Trinity v United States, 143 US 457 (1892).

76242 US 470,490 (1917) ("[T]he language being plain ... it is the sole evidence of the ultimate legislative intent.").

77282 US 55, 60 (1930) (holding that statutes may be interpreted flexibly only when literal interpretation would create an "absurdity ... so gross as to shock the general moral or common sense").

78 United States $v$ American Trucking Assocs, Inc, 310 US 534 (1940).

79 Id at 543-44 (internal quotations omitted).

80 See William N. Eskridge, Jr., Dynamic Statutory Interpretation 219 (Cambridge 1994) 
ger Court, inconsistent in this as in many other things, nonetheless moved some way in the direction of greater formality in famously literalist decisions such as United States $v$ Locke, Griffin $v$ Oceanic Contractors, Inc, and TVA v Hill. ${ }^{83}$ The Rehnquist Court, continuing this trend, often reads general commands as unqualified rules. ${ }^{84}$ And no one will be surprised if a future Court resurrects a purposive approach in such cases.

Cycling mechanisms can explain these fluctuations but cannot predict their occurrence, given that the period of the cycles is unknown and perhaps unknowable. Exogenous approaches, however, fail to explain the fluctuations at all, unless we have recourse to a grab bag of explanations of the sort that attributes the Burger Court's textualism to rising oil prices. That will not serve to explain the popularity of text-based interpretive approaches in the period before World War I, so to explain that period the exogenous approaches must point to contemporaneous change in some quite different independent variable that also happened to affect the popularity of textualism. A distinct explanation must be supplied for every periodic switch in the Court's interpretive direction. Perhaps there is no helping such explanatory profligacy for some features of interpretive practice, but where possible it should be avoided. The most sensible working hypothesis about the Court's treatment of general statutory commands is that the fluctuating popularity of textual and purposive approaches to such cases has less to do with external politics than with the endogenous mechanisms that cause doctrinal cycling.

\section{Legislative history.}

In principle the scholarly impression of cyclical trends in cases of excessive generality should also imply corresponding fluctuation in the use of legislative history, since flexible, purposive interpretations

("[T] he Justices [of the Warren Court] seized on the law-as-purpose features of legal process thought to liberalize federal habeas corpus, labor law, antitrust statutes, immigration law, regulatory policy, selective service requirements, and civil rights statutes.") (internal citations omitted). Eskridge gives many examples of purposive interpretation generally. For cases of excessive generality in particular, see, for example, Ray v Pierson, 386 US 547 (1967) (reading judicial immunity into unqualified text of 42 USC $\S 1983$ ); National Woodwork Manufacturers Association v $N L R B, 386$ US 612, 619 (1967) (citing Holy Trinity, 143 US at 459, for the position that even unambiguous statutory texts must be molded to fit the legislative purposes).

81471 US 84 (1985) (interpreting literally a statutory deadline).

82458 US 564 (1982) (interpreting literally a statutory punitive damages provision).

83437 US 153 (1978) (interpreting literally the Endangered Species Act).

84 See, for example, Pennsylvania Department of Corrections v Yeskey, 524 US 206, 209, 213 (1998) (denying state's claim for exemption from general language of Americans with Disabilities Act); Brogan v United States, 522 US 398, 408 (1998) (declining to recognize the "exculpatory no" doctrine as an exception to 18 USC $\$ 1001$ (1988), a statute forbidding a person to "knowingly ... make[ ] any false, fictitious, or fraudulent statement" to a government agency). 
of general text often appeal to legislative history to supply authority for the Court's claims about legislative purpose, while rule-bound interpretations are less likely to do so. (These are large generalizations with notable exceptions, of course; cases such as TVA $v$ Hill show that literalist interpretations of general texts sometimes appeal to legislative history to support their textual readings. ${ }^{85}$ ) What information we have suggests that cycling mechanisms are a necessary part of any positive account of legislative history usage, although they do not provide a complete and sufficient account.

Recent empirical work has begun to illuminate the history of legislative history in the Supreme Court. The data are spotty, but there are enough to indicate major peaks and valleys. We have little from the period between 1892 and 1937. Despite the enthusiastic reception accorded Holy Trinity by a few leading treatises, the cases suggest that the use of legislative history grew quite slowly between 1892 and about $1930 ;{ }^{86}$ it may even have decreased slightly at the beginning of the century. The data improve after 1937 , thanks to some important empirical work summarized and expanded in the Appendix. ${ }^{87}$ Combining published data with new research, Table 1 lists, for each term of the Supreme Court between 1938 and 1998, the total citations to legislative history, the number of merits cases on the Court's docket, the number of statutory cases (between 1948 and 1998 only), and the two corresponding ratios of citations per case and citations per statutory case. ${ }^{88}$ Graph 1 ("Citations per Case 1938-1998") puts the first ratio in

85 See 437 US at 153 (confirming literal interpretation by extensive examination of legislative history and statutory purposes).

86 Solan, $40 \mathrm{Wm} \&$ Mary L Rev at 99-100 (cited in note 72), provides results of a database search to demonstrate that

the Court was slow to embrace the examination of legislative history as part of its routine methodology, and only came to do so during the New Deal. Prior to the New Deal, reference to legislative history became more common, with some significant cases resorting to it, but it was still not the norm.

(internal citations omitted).

87 In what follows I have drawn principally upon Michael H. Koby, The Supreme Court's Declining Reliance on Legislative History: The Impact of Justice Scalia's Critique, $36 \mathrm{Harv} \mathrm{J}$ on Legis 369, 384-85 (1999) (arguing that Justice Scalia's opposition to the use of legislative history "contributed significantly to a sharp reduction in the Court's use of legislative history"); Jorge $L$. Carro and Andrew Brann, The U.S. Supreme Court and the Use of Legislative Histories: A Statistical Analysis, 22 Jurimet J 294, 298-303 (1982) (detailing Supreme Court use of legislative history from 1938 to 1979). Other important empirical studies of legislative history are collected in Vermeule, 75 NYU L Rev at $131 \mathrm{n} 217$ (cited in note 73).

88 Carro and Brann provide a count of total citations per term from 1938 to 1979 . See Carro and Brann, 22 Jurimet $\mathrm{J}$ at 303 (cited in note 87). Koby provides a count of total citations per term, total cases heard per term, and total statutory cases per term, for the period from 1980 to 1998. See Koby, 36 Harv J on Legis at 385 (cited in note 87). Stephanie Morris, a student at the University of Chicago Law School, added a count of total cases heard per term from 1938 and total statutory cases per term from 1948. This essentially extends Koby's work back through 1938. The sources for these figures are as follows. For the total number of citations per term be- 
pictorial form; Graph 2 ("Citations per Statutory Case 1948-1997") does the same for the second ratio; and Graph 3 ("Legislative History in the Supreme Court 1938-1998") combines the two into a single display.

A cycling explanation can account for some features of this data, but not all. The first important empirical study of legislative history concluded that the Court's use of legislative history rose continuously throughout the century, ${ }^{89}$ but that claim failed fully to control for the number of cases the Court decided in any given term. The revised statistics in Table 1 suggest an oscillating pattern of use, one that rises from 1938 until 1949, falls again until 1958, then fluctuates uncertainly until a dramatic upward spike occurs in the mid-1970s. That spike begins a slow downward trend in the mid-1980s, rises again in the mid1990 s, and falls again towards the end of the decade. Clearly the surge in absolute levels of legislative history usage during the 1970 s demands explanation, and it seems likely that exogenous causes are involved. The most plausible candidate would be the increase in major federal regulatory enactments during the 1960 s and 1970 s, enactments that often contained detailed legislative history in which Congress attempted to constrain the discretion of federal agencies. ${ }^{91}$ But it also appears that there is fluctuation in the pattern of usage relative to some base level that obtains in any given period. That fluctuation is consistent with the pressures exerted by cycling mechanisms, even if exogenous factors determine absolute levels.

Every upturn or downturn in the data can also be explained by exogenous factors, but here, as elsewhere, it is the infallibility of the exogenous explanation that makes it suspect. The downturn in usage in the mid-1980s might be explained by Justice Scalia's accession in 1986, while the upturn after 1992 can be explained by the accession of two relatively purposivist Justices, Ginsburg and Breyer. Substantive quibbles can be raised against both of these explanations. It is hard to ascribe the whole decline after 1986 to Justice Scalia's immediate influence, given that all the other Justices explicitly rejected his views."

fore 1980, see Carro and Brann, 22 Jurimet J at 294. For the total number of cases per term before 1980, see Bureau of the Census, Historical Statistics of the United States: Colonial Times to 1970 Part 1 at 417 (Bicentennial ed 1975); Bureau of the Census, Statistical Abstract of the United States: 1979191 (100th ed 1979). For the total number of statutory cases per term before 1980, see The Supreme Court: The Statistics, 63 Harv L Rev through 111 Harv L Rev (1949-98).

89 See Carro and Brann, 22 Jurimet J at 302 (cited in note 87).

90 See Robert C. Clark, Why So Many Lawyers? Are They Good or Bad?, 61 Fordham L Rev 275, 292-93 (1992) (describing "the appearance in the late 1960s and early 1970s of massively important and complicated regulatory initiatives").

91 See Peter H. Schuck, Delegation and Democracy: Comments on David Schoenbrod, 20 Cardozo L Rev 775, 793 n 28 (1999) (noting that statutes "enacted during the early 1970s, when government was divided, contained many more controls over agency discretion").

92 See Wisconsin Public Intervenor v Mortier, 501 US 597, 610 n 4 (1991) (disagreeing with 
Similarly, Ginsburg and Breyer replaced Justices (White and Blackmun) who also approved of legislative history, so the upturn around 1992 may not be causally related to their arrival.

But the real problem is methodological, not substantive. If one such exogenous story is unpersuasive, a better one can always be found. Each such story is good for only one reversal in the long-term oscillation; the story about Justice Scalia's accession will not explain any previous declines, and with the very arguable exception of Justice Jackson, there are no similarly textualist Justices to point to on the twentieth-century Court. Likewise, explaining upturns by reference to the arrival of intentionalist Justices will not do for upturns during the whole period between 1938 and (say) 1986, a period in which almost all of the Justices were intentionalist in a real sense. The advantage of cycling mechanisms is that they provide a far simpler account, one based upon a single form of explanation for all the fluctuations in the data. Pending better information about the history of legislative history, and more sophisticated empirical treatment, ${ }^{93}$ cycling mechanisms should receive due attention from those conducting empirical studies of interpretive change.

\section{CONCLUSION}

The legislative history discussion reemphasizes a critical qualification: the interpretive system is not self-contained, so explanations for interpretive change based on exogenous shocks will sometimes prove inescapable. But the methodological drawbacks of such explanations should make them a last resort, and the very prevalence of exogenous explanations increases the intellectual returns from considering the neglected category of endogenous explanations for interpretive change. ${ }^{94}$ Cycling mechanisms based upon models of self-defeating expectations, perhaps the most prominent type of endogenous explanation, capture a floating impression among legislation scholars that there are recognizable (albeit not predictable) ebbs and flows to interpretive practice.

Justice Scalia on the use of legislative history, eight justices conclude that "the practice will likewise reach well into the future").

93 Other variables might be considered in explaining the data in Table 1-the length of Supreme Court opinions, for example.

94 Compare Hirschman, Shifting Involvements at 5 (cited in note 4) (employing a model of cycling between public affairs and private life to explain recent American history). 
Table 1

\begin{tabular}{|c|c|c|c|c|c|}
\hline Year & Citations & Cases & $\begin{array}{l}\text { Citations } \\
\text { per Case }\end{array}$ & \begin{tabular}{|c|}
$\begin{array}{c}\text { Statutory } \\
\text { Cases }\end{array}$ \\
\end{tabular} & $\begin{array}{l}\text { Citations per } \\
\text { Statutory Case }\end{array}$ \\
\hline 1938 & 19 & 179 & 0.106 & & \\
\hline 1939 & 35 & 160 & 0.219 & & \\
\hline 1940 & 74 & 281 & 0.263 & & \\
\hline 1941 & 100 & 376 & 0.266 & & \\
\hline 1942 & 108 & 259 & 0.417 & & \\
\hline 1943 & 188 & 210 & 0.895 & & \\
\hline 1944 & 102 & 274 & 0.372 & & \\
\hline 1945 & 141 & 215 & 0.656 & & \\
\hline 1946 & 169 & 256 & 0.660 & & \\
\hline 1947 & 145 & 208 & 0.697 & & \\
\hline 1948 & 167 & 238 & 0.702 & 66 & 2.530 \\
\hline 1949 & 155 & 202 & 0.767 & 57 & 2.719 \\
\hline 1950 & 119 & 191 & 0.623 & 55 & 2.164 \\
\hline 1951 & 94 & 197 & 0.477 & 42 & 2.238 \\
\hline 1952 & 124 & 193 & 0.642 & 61 & 2.033 \\
\hline 1953 & 137 & 170 & 0.806 & 41 & 3.341 \\
\hline 1954 & 96 & 196 & 0.490 & 50 & 1.920 \\
\hline 1955 & 89 & 246 & 0.362 & 53 & 1.679 \\
\hline 1956 & 70 & 266 & 0.263 & 63 & 1.111 \\
\hline 1957 & 227 & 323 & 0.703 & 71 & 3.197 \\
\hline 1958 & 138 & 275 & 0.502 & 50 & 2.760 \\
\hline 1959 & 103 & 249 & 0.414 & 46 & 2.239 \\
\hline 1960 & 165 & 282 & 0.585 & 55 & 3.000 \\
\hline 1961 & 197 & 264 & 0.746 & 53 & 3.717 \\
\hline 1962 & 166 & 388 & 0.428 & 61 & 2.721 \\
\hline 1963 & 219 & 393 & 0.557 & 61 & 3.590 \\
\hline 1964 & 178 & 275 & 0.647 & 51 & 3.490 \\
\hline 1965 & 174 & 338 & 0.515 & 56 & 3.107 \\
\hline 1966 & 197 & 402 & 0.490 & 55 & 3.582 \\
\hline 1967 & 195 & 462 & 0.422 & 53 & 3.679 \\
\hline 1968 & 161 & 346 & 0.465 & 41 & 3.927 \\
\hline 1969 & 217 & 347 & 0.625 & 55 & 3.945 \\
\hline 1970 & 122 & 257 & 0.475 & 39 & 3.128 \\
\hline 1971 & 168 & 296 & 0.568 & 50 & 3.360 \\
\hline 1972 & 188 & 317 & 0.593 & 56 & 3.357 \\
\hline 1973 & 416 & 309 & 1.346 & 60 & 6.933 \\
\hline 1974 & 445 & 287 & 1.551 & 58 & 7.672 \\
\hline
\end{tabular}


Table 1 (Continued)

\begin{tabular}{|c|c|c|c|c|c|}
\hline Year & Citations & Cases & $\begin{array}{c}\text { Citations } \\
\text { per Case }\end{array}$ & $\begin{array}{c}\text { Statutory } \\
\text { Cases }\end{array}$ & $\begin{array}{c}\text { Citations per } \\
\text { Statutory Case }\end{array}$ \\
\hline 1975 & 326 & 204 & 1.598 & 60 & 5.433 \\
\hline 1976 & 297 & 211 & 1.408 & 39 & 7.615 \\
\hline 1977 & 293 & 206 & 1.422 & 59 & 4.966 \\
\hline 1978 & 336 & 221 & 1.520 & 51 & 6.588 \\
\hline 1979 & 405 & 182 & 2.225 & 67 & 6.045 \\
\hline 1980 & 479 & 156 & 3.071 & 56 & 8.554 \\
\hline 1981 & 499 & 154 & 3.240 & 59 & 8.458 \\
\hline 1982 & 444 & 184 & 2.413 & 76 & 5.842 \\
\hline 1983 & 776 & 183 & 4.240 & 62 & 12.516 \\
\hline 1984 & 784 & 184 & 4.261 & 62 & 12.645 \\
\hline 1985 & 796 & 175 & 4.549 & 48 & 16.583 \\
\hline 1986 & 415 & 172 & 2.413 & 49 & 8.469 \\
\hline 1987 & 380 & 175 & 2.171 & 66 & 5.758 \\
\hline 1988 & 402 & 167 & 2.407 & 47 & 8.553 \\
\hline 1989 & 411 & 170 & 2.418 & 49 & 8.388 \\
\hline 1990 & 253 & 146 & 1.733 & 54 & 4.685 \\
\hline 1991 & 266 & 125 & 2.128 & 54 & 4.926 \\
\hline 1992 & 152 & 127 & 1.197 & 54 & 2.815 \\
\hline 1993 & 178 & 116 & 1.534 & 37 & 4.811 \\
\hline 1994 & 169 & 99 & 1.707 & 39 & 4.333 \\
\hline 1995 & 110 & 94 & 1.170 & 42 & 2.619 \\
\hline 1996 & 217 & 90 & 2.411 & 30 & 7.233 \\
\hline 1997 & 103 & 90 & 1.144 & 41 & 2.512 \\
\hline 1998 & 79 & 94 & 0.840 & & \\
\hline & & & & & \\
\hline
\end{tabular}




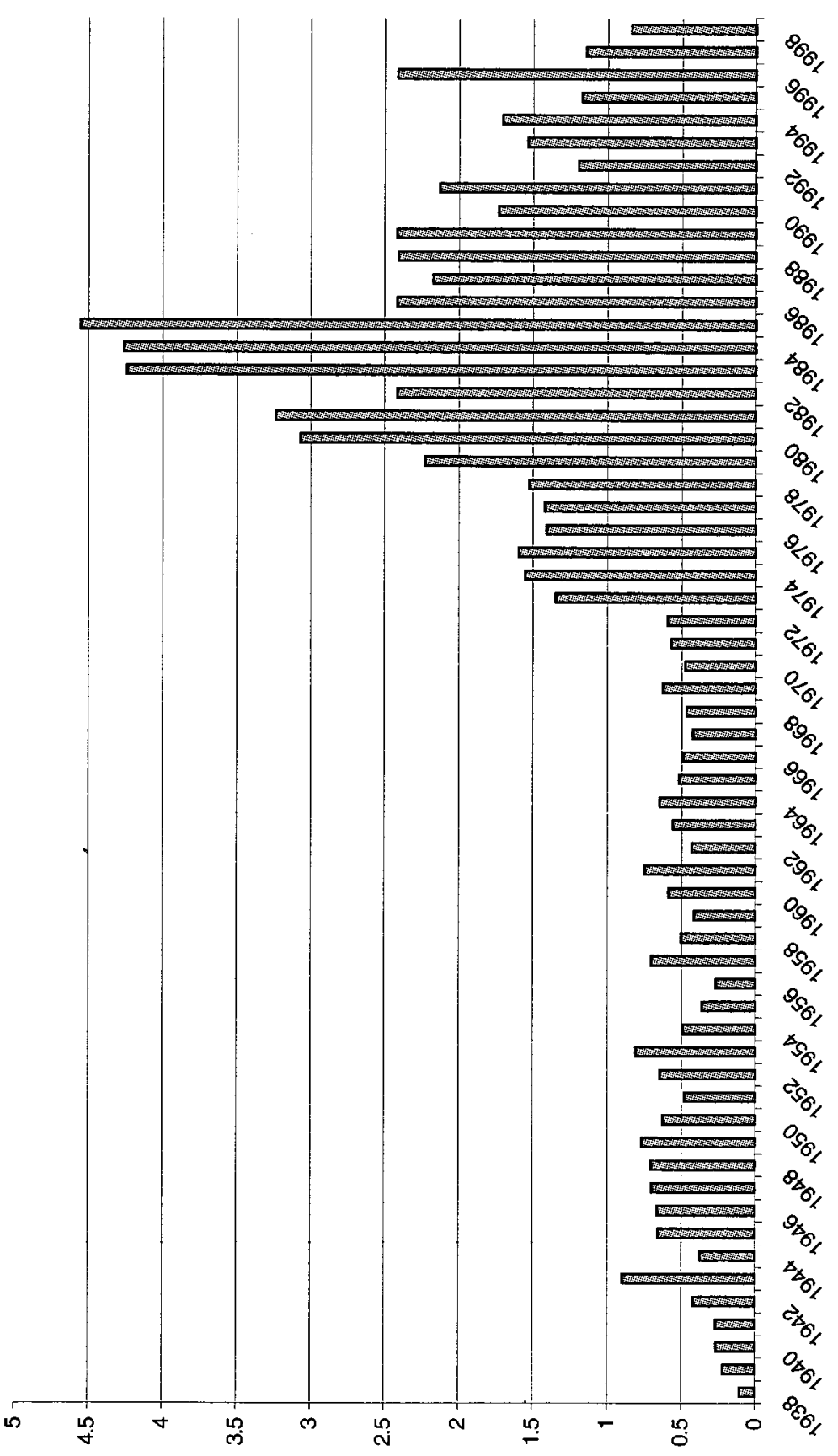




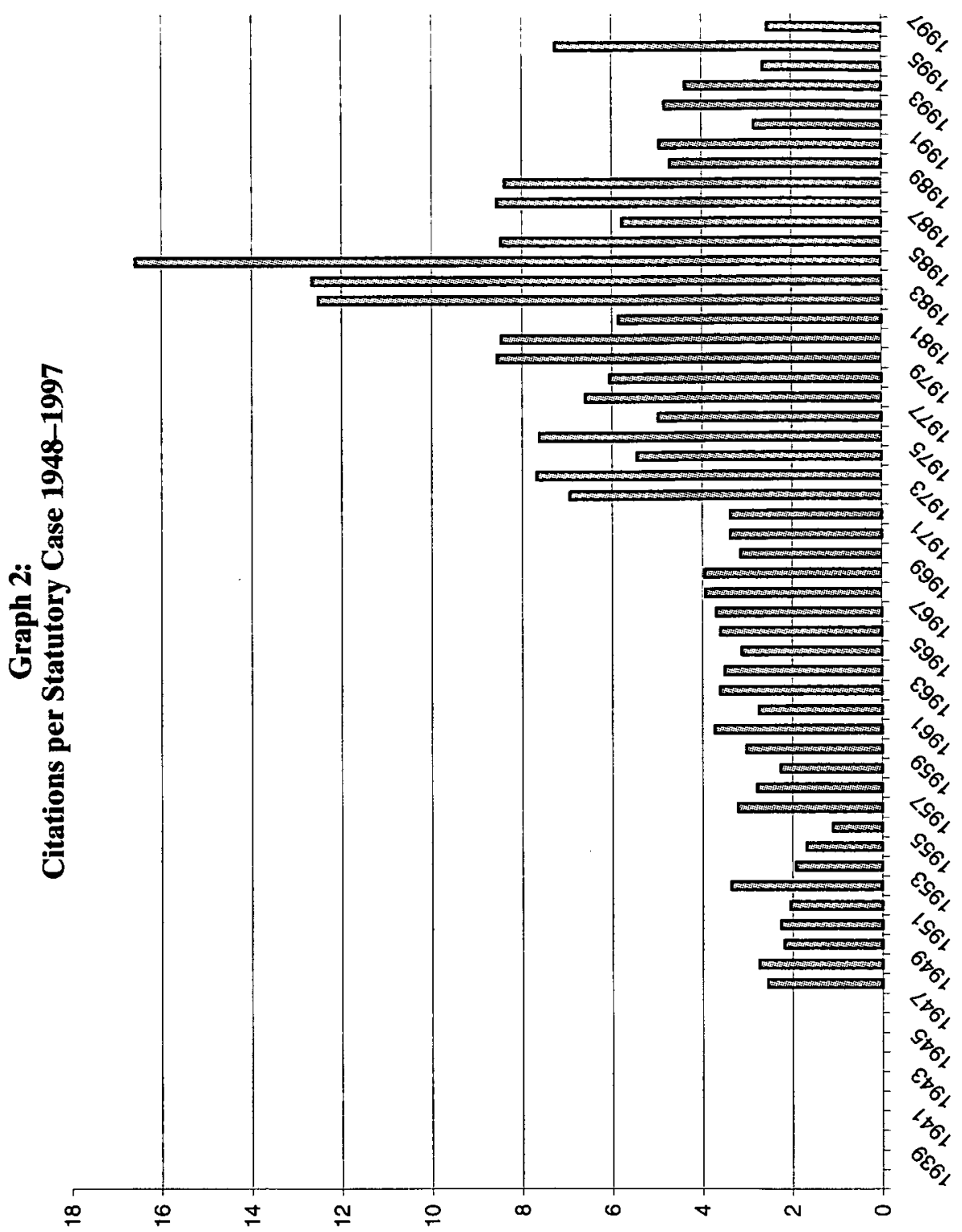




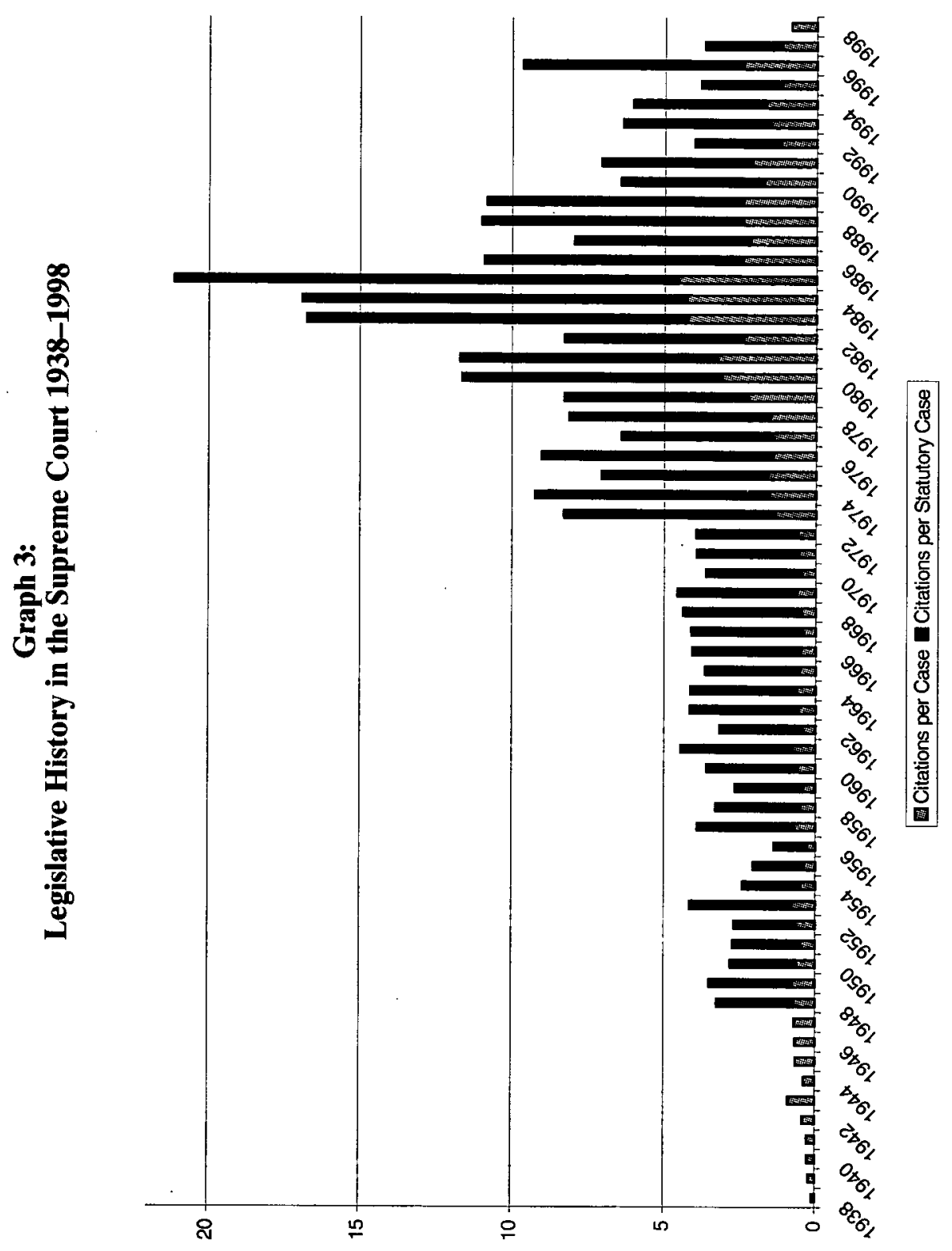

